\title{
Molecular Basis of Mammalian Gamete Binding
}

\author{
David J. Miller, Xudong Shi, And Heather Burkin
}

Department of Animal Sciences, University of Illinois at Urbana-Champaign, Urbana, Illinois 61801

\begin{abstract}
Despite the importance of fertilization for controlling human reproduction, regulating animal production, and promoting preservation of endangered species, the molecular basis underlying gamete binding and fertilization has been perplexing. More progress has been made in the mouse than in other mammals and, recently, targeted deletion of specific genes in the mouse has yielded intriguing results. This review will emphasize research performed by our laboratory and others done primarily with mouse gametes but will include some interesting observations from other mammals. Studies of murine fertilization indicate that oligosaccharides on the egg coat glycoprotein ZP3 bind sperm. The precise oligosaccharides that bind sperm are the subject of considerable debate. ZP3 also induces exocytosis of the sperm acrosome, allowing sperm to penetrate through the egg coat (zona pellucida). A number of candidate ZP3 receptors have been proposed and studies of $\beta 1$,4galactosyltransferase-I (GalT-I) are reviewed here in the most detail. Sperm from mice with a targeted deletion of GalT-I still are able to bind the zona pellucida but are unable to acrosome react and penetrate through the zona. Therefore, the unique role of GalT-I appears to be in signal transduction. GalT-I forms a complex with heterotrimeric $\mathrm{G}$ proteins and activates signaling, leading to exocytosis in sperm and in heterologous cells expressing GalT-I. Other signaling steps triggered by GalT-I are under active investigation; this receptor forms a complex with a protein kinase anchoring protein. After exocytosis of the acrosome, sperm penetrate the zona pellucida and fuse with the oocyte plasma membrane using ADAM family members on sperm and integrins on oocytes. These proteins, along with the tetraspanins on oocytes, may form a complex web at gamete fusion. Targeted deletion of specific genes in this putative complex has provided important information about their redundancy. After the oocyte is fertilized, the binding site for GalT-I is lost from ZP3, preventing additional sperm from binding to the zona pellucida. New technical advances and creative ideas offer the opportunity to make important advances and to solve the conundrum of fertilization.
\end{abstract}

\section{Introduction}

Fertilization is one of the most fascinating processes in biology. This interaction between highly specialized cells provides a unique example of many cellular processes, including specific cell adhesion, cell signaling, regulated exocytosis, cell migration, cell fusion, and regulation of the cell cycle (Figure 1). For example, gamete recognition proteins that mediate species-restricted spermoocyte interactions provide a model of highly specific cell recognition events. At fertilization, sperm must bind to the oocyte extracellular matrix (zona pellucida), 

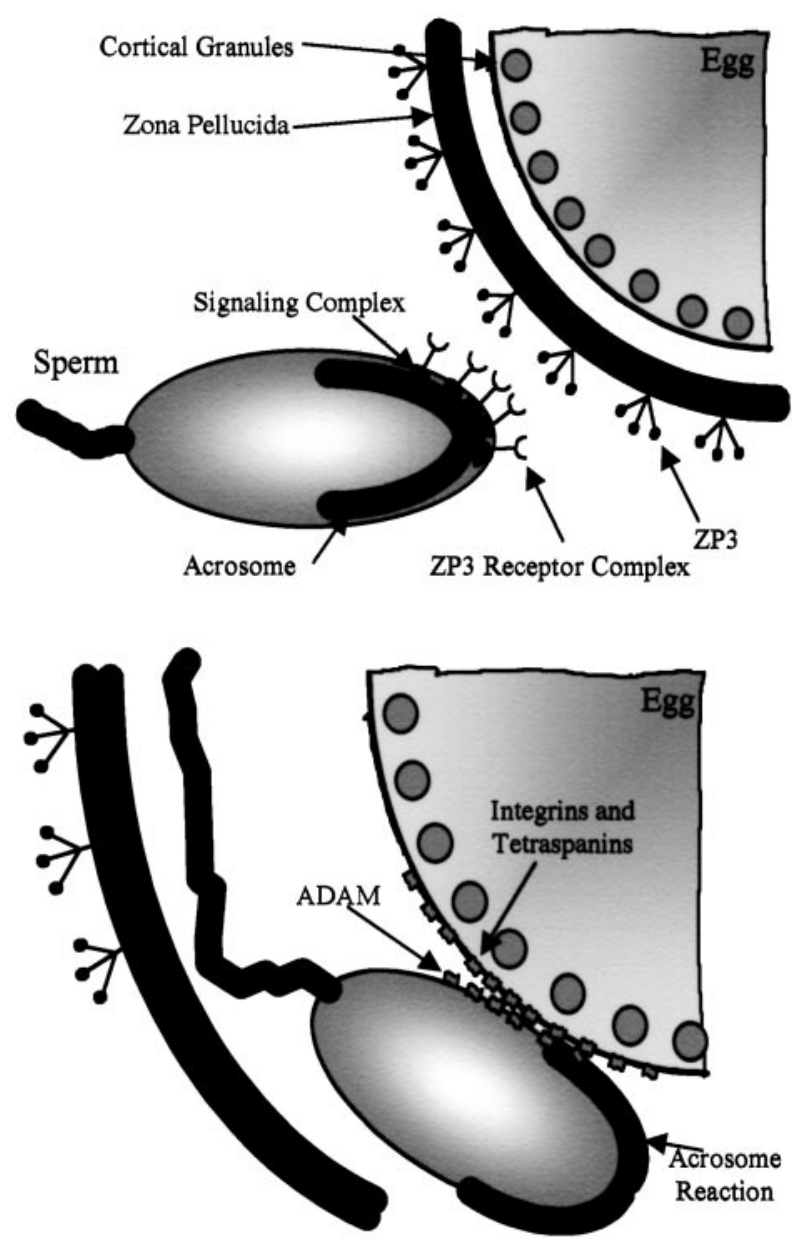

FIG. 1. Schematic working model of fertilization. Acrosome-intact sperm complete capacitation and bind to the zona pellucida. ZP3 binds mouse sperm through a receptor or receptor complex that includes GalT-I (upper panel, see text). GalT-I binding activates heterotrimeric G proteins and perhaps other signaling proteins in a complex and triggers the exocytosis of the sperm acrosome. Once the fertilizing sperm completes the acrosome reaction, it migrates through the zona pellucida and binds and fuses with the oocyte plasma membrane, using ADAM family members on sperm that interact with integrins in a complex with tetraspanins on the oocyte plasma membrane (lower panel). Fusion activates the oocyte, releasing cortical granules whose secretion modifies the zona pellucida so that additional sperm do not bind the zona.

activate the release of a large, specialized secretory vesicle (the acrosome), and penetrate through the tough zona pellucida (Yanagimachi, 1994). Oocytes from some species retain a layer of somatic cells at fertilization called cumulus cells. 
These cells and their matrix are an added barrier that sperm must traverse. After moving through the cumulus matrix and the zona pellucida, the fertilizing sperm must bind to and fuse with the oocyte plasma membrane, resulting in oocyte activation. During activation, the oocyte, previously suspended in metaphase II, completes meiosis and triggers mechanisms to stop additional sperm from penetrating through the zona pellucida and causing polyspermy (Yanagimachi, 1994). This complex series of cell interactions allows the formation of a new diploid cell (zygote) that can develop into the wide variety of tissues found in adult animals.

A better understanding of fertilization is vital to improving or controlling fertility. Once the molecular basis underlying fertilization is elucidated, one can develop specific tests to diagnose the causes of reduced fertility and therapies to treat the specific cause. One could also develop new alternatives for contraception, to regulate the population of humans and pests. Despite the importance of fertilization, a clear understanding of the molecular details has been elusive. This review will present our work and that of others aimed at understanding this process. Excellent reviews emphasizing other aspects of fertilization have been published recently (Rankin and Dean, 2000; Nixon et al., 2001; Wassarman et al., 2001).

\section{Sperm-Zona Pellucida Binding}

The initial step in gamete interaction in oocytes that lack cumulus cells is sperm binding to the oocyte's zona pellucida. Although sperm-zona binding is not completely species specific, it appears to be largely species restricted (Schmell and Gulyas, 1980; Moller et al., 1990; Rankin and Dean, 2000). The zona pellucida is a porous but tough and rigid extracellular matrix. Sperm bind to this formidable barrier and must exocytose the acrosome in order to pass through the matrix (Yanagimachi, 1994). Considerable evidence produced during the last 20 years suggests that sperm binding to the zona pellucida is a carbohydrate-mediated process (Nixon et al., 2001; Wassarman and Litscher, 2001; Wassarman et al., 2001). Lectin-like proteins on sperm bind to oligosaccharides on the zona pellucida proteins. This paradigm is probably similar to the binding of sperm to invertebrate oocytes as well as lymphocyte homing, binding of pathogens to their cellular hosts, and binding of pollen to plant stigma (Wassarman and Litscher, 2001). The plethora of possible combinations of monosaccharides that can be synthesized may provide the observed species restrictions in sperm-zona binding.

Because each zona pellucida component is embedded in a matrix, investigators initially had to solubilize and purify each zona protein to study its function. The individual components of the mouse zona pellucida were studied following heat or acid solubilization and separation by size. The original 
approach to identify the function of zona proteins was to add each protein to sperm and determine which would bind sperm and competitively block sperm binding to oocytes (Bleil and Wassarman, 1980). Under these conditions, only one of the three zona proteins, ZP3, blocked binding of sperm to oocytes (Bleil and Wassarman, 1980). Similarly, in direct binding assays, ZP3 bound to acrosome-intact sperm but lower binding was observed to acrosome-reacted sperm (Bleil and Wassarman, 1986; Mortillo and Wassarman, 1991). ZP3 is the smallest of the proteins, with an apparent molecular weight of $83 \mathrm{kDa}$ (Bleil and Wassarman, 1980). The other two proteins, ZP1 and ZP2, have molecular weights of about 200 and $120 \mathrm{kDa}$, respectively. All three zona proteins are glycoproteins and appear as broad bands by SDS-PAGE (sodium dodecyl sulfate-polyacrylamide gel electrophoresis) due to heterogeneous glycosylation (Rankin and Dean, 2000; Wassarman and Litscher, 2001). Oligosaccharides are found on all three glycoproteins on both asparagine (N-linked) and serine/ threonine (O-linked) residues (Shimizu et al., 1983; Florman and Wassarman, 1985). Most evidence indicates that O-linked oligosaccharides of ZP3 bind mouse sperm (Florman and Wassarman, 1985), although there is recent evidence that N-linked oligosaccharides also may have binding activity in other species (Nakano and Yonezawa, 2001). Based on site-directed mutagenesis, the O-linked oligosaccharides that bind mouse sperm appear to be linked to ZP3 at serine-332 and serine-334, found in the carboxy terminal half of ZP3 (Chen et al., 1998). This region appears to be the most polymorphic among species (discussed in greater detail below) (Wassarman and Litscher, 2001; Wassarman et al., 2001).

\section{A. IDENTITY OF SPERM-BINDING OLIGOSACCHARIDES IN THE ZONA PELLUCIDA}

The precise oligosaccharides on ZP3 that bind sperm have not been identified. There are conflicting data regarding the nonreducing terminal monosaccharide that is necessary to bind sperm. Removing or blocking $\mathrm{N}$-acetylglucosamine residues from ZP3 blocks sperm binding (Shur and Hall, 1982a; Lopez et al., 1985; Miller et al., 1992). Similarly, removal of mannose, $\alpha$-galactose, or fucose residues from ZP3 blocks sperm binding (Bleil and Wassarman, 1988; Cornwall et al., 1991). Synthetic oligosaccharides containing $\alpha$-galactose, $\beta$-galactose, or mannose residues as terminal monosaccharides inhibit sperm binding competitively (Cornwall et al., 1991; Litscher et al., 1995; Johnston et al., 1998). Recent analysis of the composition of the entire mouse zona pellucida suggested structures for over 20 high mannose and complex N-linked structures, many of which contained these residues. In contrast, these investigators recovered less total O-linked oligosaccharide, the oligosaccharides that are believed to bind mouse sperm. Structures for only 10 to 13 O-linked oligosaccharides could be proposed (Easton et al., 2000). A problem with analyzing the total composition 
of the zona pellucida or purified ZP3 is that oligosaccharides in the zona pellucida are not distributed homogeneously. For example, terminal $\alpha$-galactosyl residues are distributed primarily in the inner half of the zona pellucida, whereas other terminal monosaccharides such as $\mathrm{N}$-acetylglucosamine residues are distributed homogeneously throughout the zona pellucida (Aviles et al., 2000). This heterogeneity is also a problem when interpreting the effect of adding soluble ZP3 or glycosidase-treated ZP3 because some of the ZP3 would be from the inner portion of the zona and not be exposed to sperm at initial binding. The necessity of $\alpha$-galactosyl residues is also in doubt because oocytes from mice bearing null mutations in $\alpha 1,3$-galactosyltransferase have normal fertility (Thall et al., 1995). The precise structure of the oligosaccharides that bind sperm remains unresolved. Additional studies of intact oocytes from mice engineered to have specific mutations or deletions in glycosyltransferases will probably provide the most compelling information about which oligosaccharides are crucial for sperm binding.

While it is generally agreed that, in mice, oligosaccharides of ZP3 are responsible for binding sperm, in other animals, the situation is less clear. In domestic pigs and cattle, there is evidence that ZP1, perhaps in a complex with ZP3, binds sperm (Kudo et al., 1998; Yurewicz, et al., 1998; Yonezawa et al., 2001). The sperm-binding activity of ZP1 (sometimes called ZPB or ZP3 $\alpha$ ) is contrary to the lack of sperm-binding activity of ZP1 in mice. A nagging problem with the porcine and bovine zona and the zona pellucida proteins from some other species is that they have not been purified without partial deglycosylation. All studies performed with individual porcine zona proteins have used endo- $\beta$ galactosidase-treated proteins. Although endo- $\beta$-galactosidase-treated porcine ZP1 retains some sperm-binding activity, partial deglycosylation of other zona proteins may influence their sperm receptor activity. A second consideration is that removal of some oligosaccharides from ZP1 by endo- $\beta$-galactosidase may expose cryptic sperm-binding oligosaccharides. Conclusions about the biological activity of purified porcine zona proteins have this caveat. Another difference between the porcine and mouse zona is evidence that the sperm-binding oligosaccharides may be linked to the porcine zona protein through both asparagine and serine/threonine linkages (Yurewicz et al., 1992; Yonezawa et al., 1997; Nakano and Yonezawa, 2001). Further study is necessary to determine whether the glycosylation differences may contribute to species specificity during spermoocyte binding. The possibility that each species may process ZP3 differently is supported by evidence from mice that express human ZP3 but have a null mutation in mouse ZP3. Oocytes from these mice form a normal-appearing zona but do not bind human sperm; instead, they bind mouse sperm (Rankin et al., 1998). One interpretation is that mouse oocytes process ZP3 in a unique way, allowing human ZP3 to have the biological activity of mouse ZP3. 
The evidence that porcine and bovine ZP1 homologues bind sperm raises the issue that mouse ZP1 or ZP2 may bind sperm. One would not expect that species would use different zona proteins to bind sperm but, instead, species might use unique variants of the same gamete receptors. In the initial experiments testing their activity, denatured soluble ZP1, ZP2, and ZP3 were individually tested for their ability to bind sperm and competitively inhibit sperm binding to oocytes. Only ZP3 was active (Bleil and Wassarman, 1980). Soluble ZP2 bound to acrosome-reacted sperm (Bleil et al., 1988) but neither ZP1 or ZP2 had an effect on acrosome-intact sperm. A proviso is that denaturation may have negated any biological activity of ZP1 and ZP2. Because zona proteins are deposited into an insoluble matrix, they are denatured to solubilize and purify them. An alternative is to synthesize recombinant zona proteins individually. Importantly, the recombinant zona proteins must be post-translationally processed by the cell as they would be by the oocyte, the cell that synthesizes zona proteins in most mammals (Rankin and Dean, 2000; Wassarman and Litscher, 2001). In the absence of careful oligosaccharide analysis, one must question results with recombinant zona proteins. Recombinant ZP3 produced by embryonal carcinoma cells and Chinese hamster ovary $(\mathrm{CHO})$ cells appears to be processed by these cells similarly but not exactly the way oocytes process ZP3. Like oocyte-produced $\mathrm{ZP} 3$, recombinant mouse ZP3 produced by embryonal carcinoma and $\mathrm{CHO}$ cells binds mouse sperm (Kinloch et al., 1991; van Duin et al., 1994; Brewis et al., 1996). But, unlike oocyte-produced mouse ZP3, which binds hamster sperm (Moller et al., 1990), recombinant mouse ZP3 expressed in somatic cells does not bind hamster sperm (Kinloch et al., 1991; Litscher and Wassarman, 1996). The glycosylation of other recombinant zona proteins has not been analyzed and their biological activity in purified native form has not been tested. But oocytes from mice with null mutations in ZP1 still are able to bind sperm (Rankin et al., 1999). Clearly, ZP1 is not necessary for mouse sperm binding.

\section{B. RECEPTORS FOR ZONA PELLUCIDA PROTEINS}

A number of zona receptors on sperm have been studied but how they may function individually or collectively is not yet clear. Identifying zona receptors has proved to be more difficult than identifying the zona ligands, probably because of the greater complexity of the sperm surface, as compared to the zona pellucida. There may be multiple receptors to account for the multiple affinities of ZP3 to sperm (Thaler and Cardullo, 1996). We will discuss zona receptors based upon how they were isolated and whether they appear to be primary receptors (found on plasma membrane of acrosome-intact sperm) or secondary receptors (on acrosome-reacted sperm), although data on the location of all the candidates are not available. 
Several receptor candidates have been isolated, based on their affinity for the zona pellucida. From mouse sperm, sp56 was isolated based on its affinity for ZP3 and $\alpha$-galactose residues (Cheng et al., 1994; Bookbinder et al., 1995) while zonadhesin, proacrosin, sp38, P47, and a group of proteins called spermadhesins (all studied most on porcine sperm) were isolated based on their affinity for whole zona pellucida (Hardy and Garbers, 1995; Ensslin et al., 1998; Jansen et $a l ., 2001)$. The specific zona ligand for the latter group is unknown. Further study revealed that sp56 was found within the acrosome (Foster et al., 1997; Kim et al., 2001a). In this location, its function may be to tether sperm onto the zona pellucida as they are undergoing the acrosome reaction. Proacrosin, P-selectin, and $\mathrm{sp} 38$ are found within the acrosome and exposed during the acrosome reaction, where they can serve as secondary zona receptors (Mori et al., 1995; Geng et al., 1997; Jones et al., 1988). Although mice lacking either P-selectin or proacrosin are fertile, careful analysis of proacrosin null sperm shows that these sperm penetrate the zona pellucida more slowly (Mayadas et al., 1993; Adham et al., 1997). This is probably because the activated form of proacrosin is important for dispersal of the acrosomal matrix during the acrosome reaction (Yamagata et al., 1999). The spermadhesins and P47 are peripheral membrane proteins (Ensslin et al., 1998; Jansen et al., 2001). Many of the spermadhesins are produced by seminal vesicles (Jansen et al., 2001). Because sperm from the cauda epididymis that have not been exposed to secretions from the seminal vesicles have normal fertility, spermadhesins that are seminal vesicle products do not appear to be necessary for fertilization. Whether zonadhesin is intracellular or on the plasma membrane has not been reported (Hickox et al., 2001).

Another approach to identify zona receptors has been to develop antibodies that block sperm-zona binding. A monoclonal antibody to sperm PH-20 blocks fertilization, implicating PH-20 in zona binding (Myles and Primakoff, 1997). PH-20 is an interesting molecule that has both hyaluronidase and zona binding activity (Hunnicutt et al., 1996). It appears to have a dual role. PH-20 on the postacrosomal region of sperm and perhaps $\mathrm{PH}-20$ released by acrosomereacting sperm disperses the cumulus cells, allowing sperm passage (Hunnicutt et al., 1996). After the acrosome reaction, PH-20 binding is necessary for sperm to bind the zona pellucida (Hunnicutt et al., 1996). Therefore, PH-20 appears to be a secondary zona receptor, although the zona ligand is unknown. Sperm Sp17 is an acrosomal protein first isolated using antibodies. It has affinity for the zona pellucida and other sulfated glycoproteins (Yamasaki et al., 1995; Wen et al., 2001).

P95 is a mouse sperm protein identified by SDS-PAGE, transfer to nitrocellulose, and ligand blotting, using ZP3 as a ligand (Leyton and Saling, 1989a). Whether it is acrosomal or on the plasma membrane is not known. A sequence of the putative human homologue has been reported but the sequence may, in 
fact, be the sequence of c-mer (Burks et al., 1995; Bork, 1996; Tsai and Silver, 1996).

\section{C. $\beta 1,4$ GALACTOSYLTRANSFERASE AS A MULTIFUNCTIONAL PROTEIN}

The zona receptor candidate that has been investigated most extensively is an enzyme with two forms that have roles at two distinct regions of the cell. $\beta 1,4 \mathrm{Galactosyltransferase}$ (GalT) was named for its ability to add galactose to glycoproteins and glycolipids with terminal $\mathrm{N}$-acetylglucosamine residues. Like other glycosyltransferases, GalT-I is a type II membrane glycoprotein whose catalytic domain is in the internal compartment of the Golgi (Joziasse, 1992). In addition to its Golgi location, some GalT was discovered as a component of the plasma membrane of specific cells (Shur, 1991). More recently, other glycosyltransferases have been found on the plasma membrane, so GalT appears not to be unique (Borsig et al., 1996; Close and Colley, 1998; Mandel et al., 1999). On the plasma membrane, the catalytic domain is externally oriented. Because the typical galactose donor, uridine diphosphate (UDP)-galactose, is not present in the extracellular fluid, GalT may not be able to carry out a synthetic function. Rather, it appears to act as a lectin and bind to galactose acceptors, specific glycoproteins that have appropriately presented $\mathrm{N}$-acetylglucosamine residues at nonreducing termini (Shur, 1993).

Recently, several other gene products were discovered with GalT activity. At least six additional genes encode proteins capable of adding galactose to $\mathrm{N}$-acetylglucosamine; some of these enzymes prefer specific substrates (e.g., glycolipid rather than glycoprotein) (Amado et al., 1999). Of the seven GalTs identified, to date, only the first GalT sequenced, referred to as GalT-I, has been shown to have both plasma membrane and Golgi distributions. A variety of experiments have demonstrated that GalT-I is found on the surface of some cells. Antibodies to recombinant GalT-I or GalT-I peptides bind to the plasma membrane of live sperm and some somatic cells, as assessed by confocal microscopy (Youakim et al., 1994a; Larson and Miller, 1997; Tengowski et al., 2001). GalT-I can be detected as a biotinylated protein when sperm plasma membrane proteins are biotinylated by nonpermeable biotin analogs (Larson and Miller, 1997). Enzyme assays of intact cells demonstrate that GalT-I is on the surface and the enzyme is detected on enriched plasma membrane fractions (FayrerHosken et al., 1991; Shur, 1991).

The GalT-I gene is unusual because, in the four mammals with sequence information, it has two translation start sites that encode two slightly different proteins (Shaper et al., 1988; Russo et al., 1990; Mengel-Gaw et al., 1991; E.A. Landers and D.J. Miller, unpublished results). One start site of the mouse gene is 39 bases upstream of the second site. When translated, this results in a long 
form of the protein that is identical to the short form, except that it has 13 additional amino acids, yielding 24 amino acids at its amino terminal cytoplasmic domain rather than 11 . Both forms share a noncleavable signal-anchor/transmembrane domain, a stem region, and long extracellular/lumenal catalytic domain. The long form is found on the plasma membrane as well as in the Golgi. This was demonstrated most convincingly using antibodies generated to the sequence specific to the long form (Youakim et al., 1994a). Only the long form is able to activate signal transduction in response to binding of a ligand (discussed below). Cells are able to specifically regulate transcription of each form. The long form appears to be constitutively synthesized in many cells. The short form can be specifically upregulated by the mammary gland during lactation, where it forms the lactose synthase complex (Shaper et al., 1998). The functions in cell adhesion, fertilization, lactation, and glycosylation demonstrate the broad importance of GalT-I. This multifunctional protein was first named for its enzyme activity in the Golgi but, in view of the breadth of actions GalT-I carries out, the name implies too narrow a function.

How GalT-I is targeted to two different locations on the cell is an intriguing question. Indeed, how glycosyltransferases are retained in the Golgi is an active area of research. There are two prominent models proposed to explain glycosyltransferase retention (Colley, 1997). One hypothesis, known as the bilayer thickness model, is that the length of the glycosyltransferase transmembrane domain mediates retention in the Golgi membrane. The shorter transmembrane domains of Golgi proteins may prevent them from entering the cholesterol-rich membranes of transport vesicles that would otherwise carry the enzymes to the plasma membrane. A second hypothesis is referred to as kin recognition. In this model, glycosyltransferases form oligomers or perhaps large hetero-oligomers that do not enter secretory vesicles. Neither model completely explains the observations in the literature. The stem region or cytoplasmic tail also may influence Golgi retention of some glycosyltransferases (Milland et al., 2001; Sasai et al., 2001). In any case, the Golgi retention mechanism must be altered or overridden for GalT-I to move to the plasma membrane.

\section{D. $\beta 1,4$ GALACTOSYLTRANSFERASE AS AN ADHESION RECEPTOR}

As a plasma membrane molecule, GalT-I can act as a receptor for specific glycoproteins, including ZP3. All known ligands for GalT-I have terminal $\mathrm{N}$-acetylglucosamine residues. Therefore, it appears that, as expected, GalT-I recognizes glycoproteins that could be galactose acceptors in the Golgi. On the other hand, terminal $\mathrm{N}$-acetylglucosamine is not sufficient for a glycoprotein to be a sperm GalT-I ligand. For example, both ZP1 and ZP2 have N-acetylglucosamine at nonreducing termini but they are not ligands for sperm GalT-I 
(Miller et al., 1992). The additional ligand requirements for sperm membranebound GalT-I are unknown and could include oligosaccharide or protein determinants. What regulates the specificity of GalT-I is not certain but it is possible that being embedded in the plasma membrane influences substrate specificity. Detergent solubilization of GalT-I from somatic cells allows the enzyme to bind to a much wider variety of ligands (Begovac et al., 1991). The soluble forms of some glycosyltransferases that are cleaved from the membrane-bound forms glycosylate substrates less efficiently (Zhu et al., 1998). In addition, the binding specificity of GalT-I could be influenced by other proteins in a putative receptor complex in the sperm plasma membrane. The question of binding specificity is an important one to understanding GalT-I function.

During spermatogenesis, GalT-I is synthesized by spermatogonia, primary and secondary spermatocytes, and round spermatids (Pratt and Shur, 1993; Charron et al., 1999). Interestingly, a unique transcript is synthesized in spermatocytes and round spermatids that, when translated, yields only the long form of the protein (Charron et al., 1999). As the round spermatids change their shape to that of mature sperm, GalT-I moves to the developing sperm head and becomes localized to the plasma membrane in the acrosomal region of sperm (Scully et al., 1987; Pratt and Shur, 1993). GalT-I from sperm behaves as a typical integral membrane protein with a molecular weight of $60 \mathrm{kDa}$ (Shur and Neely, 1988). In the epididymis, glycoconjugates in the epididymal fluid bind to GalT-I, blocking the interaction of GalT-I with other ligands such as the zona pellucida. These glycoconjugates are lost from sperm during capacitation, the final sperm maturation process that occurs in the female tract, enabling GalT-I to bind other ligands (Shur and Hall, 1982b). During fertilization, GalT-I on the mouse sperm surface binds to ZP3 but not other zona pellucida glycoproteins (Miller et al., 1992). This fulfills an important criterion for bona fide ZP3 receptors.

The biological importance of the GalT-I and ZP3 adhesion was tested in several in vitro assays. When $\mathrm{N}$-acetylglucosamine residues were either blocked or removed from soluble ZP3, it lost its ability to bind sperm (Miller et al., 1992). This suggested that the interaction between GalT-I and ZP3 was necessary for gamete binding. In similar experiments using the intact zona pellucida, blocking or removing $\mathrm{N}$-acetylglucosamine residues reduced binding of sperm (Shur and Hall, 1982a; Lopez et al., 1985). Blocking GalT-I with antibodies, $\mathrm{F}_{\mathrm{ab}}$ fragments, or $\alpha$-lactalbumin (a protein that modifies the substrate specificity of GalT-I) reduces sperm binding to the zona pellucida (Shur and Hall, 1982a; Lopez et al., 1985). Purified GalT-I from sperm blocks sperm-zona binding when added as a competitor. All these results demonstrate the important function of sperm GalT-I in zona binding.

The oligosaccharides on ZP3 that bind GalT-I have the same characteristics as oligosaccharides shown in independent experiments to bind sperm. The 
binding site for GalT-I on ZP3 was removed by mild alkaline hydrolysis but not peptide-N-glycosidase F, suggesting it was O linked (Miller et al., 1992). The chromatographic behavior of the GalT-I binding site and the active ZP3 O-linked oligosaccharides was similar (Miller et al., 1992). Further characterization of the oligosaccharides that bind sperm and GalT-I has been problematic due to the difficulty in obtaining sufficient zona pellucida glycoproteins.

\section{E. $\beta 1,4$ GALACTOSYLTRANSFERASE ACTIVATES SIGNAL TRANSDUCTION AND THE ACROSOME REACTION}

In addition to its role in binding, ZP3 is also the zona protein that triggers the acrosome reaction in sperm (Figure 1). The acrosome is a membrane-bound organelle located in the anterior portion of the head between the nucleus and the plasma membrane. During the acrosome reaction, the outer membrane of the acrosome fuses with the overlying plasma membrane and the contents of the acrosome are dispersed. This relatively slow exocytosis includes a gradual dissolution of the acrosomal matrix stored within the acrosome (Kim et al., 2001b). The acrosome reaction is required for sperm to penetrate through the zona pellucida. Isolated ZP3, purified in a soluble form from the zona pellucida or expressed in heterologous cells, induces the acrosome reaction when added to sperm (Bleil and Wassarman, 1983; Kinloch et al., 1991; Wassarman et al., 2001).

Although oligosaccharides on ZP3 bind sperm, the oligosaccharides or small glycopeptides from ZP3 are unable to induce the acrosome reaction (Florman et al., 1984; Leyton and Saling, 1989b). However, addition of antibodies to the ZP3 glycopeptides induces the acrosome reaction, supporting the model that ZP3 requires a multivalent interaction with receptors on sperm to induce signal transduction (Leyton and Saling, 1989b). Consistent with this model, each ZP3 molecule can bind two or three GalT-I molecules (Miller et al., 1992). This appears similar to the behavior of somatotropin and its receptor (Cunningham et al., 1991).

At some point during the acrosome reaction, sperm lose their affinity for ZP3 and develop an affinity for ZP2 (Bleil et al., 1988). This so-called secondary binding may maintain sperm on the zona pellucida and aid in penetration of sperm through the zona pellucida. Whereas ZP2 and ZP3 have functional roles in both zona formation and sperm binding, ZP1's major function is only structural. ZP1 appears to crosslink the other zona proteins to provide form to the matrix. In the absence of ZP1, ZP2 and ZP3 form a loose, fragile zona pellucida (Rankin et al., 1999).

The first indication that GalT-I may act as a signaling receptor was the result of experiments with GalT-I antibodies that apparently can mimic ZP3 (Macek et al., 1991). Intact immunoglobulin $\mathrm{G}$ ( $\mathrm{IgG})$ induces the acrosome reaction in 
capacitated mouse sperm but $\mathrm{F}_{\mathrm{ab}}$ fragments do not, even though they still inhibit sperm-zona binding. However, if the $\mathrm{F}_{\mathrm{ab}}$ are cross-linked with a secondary IgG, they trigger the acrosome reaction on sperm. Although this is intriguing, an alternative explanation is that $\operatorname{IgG}$ can affect sperm viability and sperm often release their acrosomes as a consequence of death. This is unlikely because control IgG did not induce the acrosome reaction. If GalT-I aggregation is sufficient to induce the acrosome reaction, a further prediction is that other multivalent GalT-I ligands would act in the same manner. This prediction was borne out in two ways. Bovine serum albumin (BSA) derivatized with $\mathrm{N}$ acetylglucosamine induces the acrosome reaction in mouse sperm but unconjugated $\mathrm{N}$-acetylglucosamine does not (Loeser and Tulsiani, 1999). The specificity of the response is in question because these authors also found that $\mathrm{N}$-acetylgalactosamine or mannose coupled to BSA induces the acrosome reaction in mouse sperm. Using polyacrylamide as a matrix, $\mathrm{N}$-acetylglucosamine on polyacrylamide triggers acrosomal exocytosis. Free $\mathrm{N}$-acetylglucosamine, polyacrylamide, or polyacrylamide derivatized with galactose have no effect (Nixon et al., 2001).

Although multivalent binding appears necessary for signal transduction through GalT-I, the state of GalT-I in the plasma membrane is not certain. In the Golgi membrane, GalT-I appears to have the ability to form multimers but its state in the plasma membrane is uncertain (Yamaguchi and Fukuda, 1995). At least two models are possible. On the plasma membrane, GalT-I may exist as a monomer and cross-linking by ZP3 or GalT-I IgG would induce signal transduction. Alternately, GalT-I in the membrane may exist as a multimer and multivalent binding induces a response in the GalT-I complex that activates signal transduction.

The signaling response elicited in sperm by ZP3 includes some components found in somatic cells. For example, during capacitation, there is an increase in tyrosine phosphorylation of sperm proteins (Visconti and Kopf, 1998). Presumably, this is caused by activation of either receptor or nonreceptor tyrosine kinases, although the identity of the activated kinases is unclear. The role of G proteins in the acrosome reaction has been studied more extensively. Induction of the acrosome reaction by ZP3 can be blocked by pertussis toxin, demonstrating that a subclass of heterotrimeric $\mathrm{G}$ proteins is necessary for the acrosome reaction (Ward and Kopf, 1993). The pertussis toxin substrates $\mathrm{G}_{\mathrm{i} 1}$ and $\mathrm{G}_{\mathrm{i} 2}$ are activated by ZP3 binding to sperm (Ward et al., 1994). G protein activation may lead to transient intracellular alkalinization, enabling a robust influx of calcium in response to zona pellucida binding (Florman et al., 1998).

If some GalT-I antibodies mimic ZP3 by acting as GalT-I agonists, one would expect they would activate signal transduction steps normally activated by ZP3. Pharmacological agents that block the ZP3-induced acrosome reaction might also block the GalT-I antibody-induced acrosome reaction. In concordance 
with this prediction, pertussis toxin blocks the GalT-I antibody-induced acrosome reaction (Gong et al., 1995). GalT-I antibodies also activate sperm G proteins, assessed by an increase in high-affinity guanosine triphosphate (GTP) binding (Gong et al., 1995). Activated G proteins hydrolyze GTP as they are inactivated. Measurement of GTP hydrolysis often is used to confirm G protein activation. Membrane preparations from sperm also increased GTP hydrolysis in response to GalT-I antibodies, supporting the hypothesis that GalT-I activates heterotrimeric $\mathrm{G}$ proteins (Figure 2).

The results suggesting that GalT-I activates G proteins were unexpected because most $G$ protein-coupled receptors span the plasma membrane seven times and GalT-I has only a single transmembrane sequence. To confirm that GalT-I interacts with G proteins, we expressed GalT-I in heterologous cells. We selected Xenopus laevis oocytes to express GalT-I because they synthesize a wide variety of heterotrimeric G proteins (Olate et al., 1990) and G protein activation leads to exocytosis (Kline et al., 1991). As expected, expression of GalT-I allowed oocytes to bind ZP3 but not ZP1 or ZP2 (Figure 3) (Shi et al., 2001). The calculated dissociation constant, although variable between ZP3 preparations, was $9 \mathrm{nM}$, intermediate between the expected affinity for low- and high-affinity ZP3 receptors (Thaler and Cardullo, 1996).

In sperm, ZP3 and antibodies to GalT-I activate G proteins and trigger the exocytosis of the acrosome. Likewise, oocytes exocytose their cortical granules when traditional G protein-coupled receptors are expressed in oocytes and the ligand is added (Kline et al., 1991). When we expressed GalT-I on Xenopus

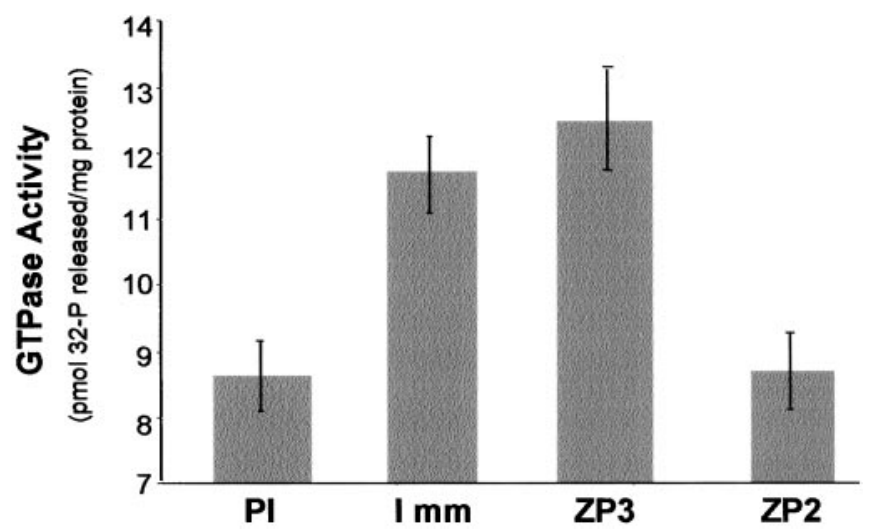

FIG. 2. Membrane preparations from sperm increase GTP hydrolysis in response to GalT-I antibodies. GTPase assays were performed using methods similar to those described elsewhere (Ward et al., 1992). GalTase antibodies or solubilized zona proteins were added to sperm membranes in reaction buffer. The samples were incubated at $30^{\circ} \mathrm{C}$ for 15 minutes. The assay was stopped and released ${ }^{32} \mathrm{P}$ was counted. Background counts were obtained from samples without membranes. 


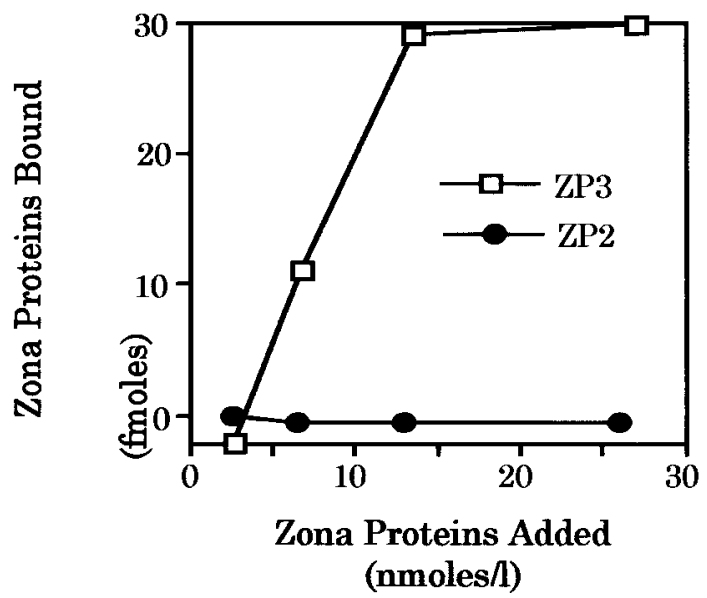

FIG. 3. ZP3, but not ZP2, bound to Xenopus oocytes expressing GalT-I. Increasing concentrations of each zona glycoprotein were added to Xenopus oocytes expressing GalT-I and water-injected control eggs. With increasing zona protein concentration, ZP3 binding increased to saturation but ZP2 binding did not differ between RNA-injected and water-injected eggs. In this ZP3 preparation, the $K_{D}$ was approximately $9 \mathrm{nM}$ but affinity was variable between ZP3 preparations. [Adapted with permission from Shi X, Amindari S, Paruchuru K, Skalla D, Burkin H, Shur BD, Miller DJ 2001 Cell surface $\beta$-1,4-galactosyltransferase-I activates $\mathrm{G}$ protein-dependent exocytotic signaling. Development 128:645-654. Copyright Company of Biologists, Ltd.]

oocytes and added GalT-I ligands, such as antibodies or ZP3, the oocytes released their cortical granules (Figures 4 and 5) (Shi et al., 2001). Indeed, the oocytes showed other indications of activation, including the elevation of the vitelline envelope and the cortical contraction. Pertussis toxin blocked oocyte activation, demonstrating that the $G$ proteins activated by GalT-I on sperm and oocytes were related. GalT-I activation by agonistic antibodies or ZP3 also activated G proteins, as indicated by increased GTP binding and GTP hydrolysis (Figures 6 and 7). Expressing GalT-I and perhaps other candidate zona receptors on Xenopus oocytes may be a fruitful way to identify the motifs of the receptors involved in signal transduction.

We have used the oocyte expression system to begin studies of the GalT-I motifs that are necessary for signal transduction and exocytosis. Although most $\mathrm{G}$ protein-coupled receptors have the traditional seven transmembrane domains, there are at least three examples of receptors that appear to couple to $\mathrm{G}$ proteins that have a single transmembrane domain (Okamoto et al., 1990, Liang and Garrison, 1991; Yang et al., 1991; Nishimoto et al., 1993; Sun et al., 1997). They are the insulin-like growth factor-II/mannose-6-phosphate receptor (IGF-II/ M6PR), amyloid protein precursor, and epidermal growth factor receptor, although the results with IGF-II/M6PR are controversial (Korner et al., 1995). 

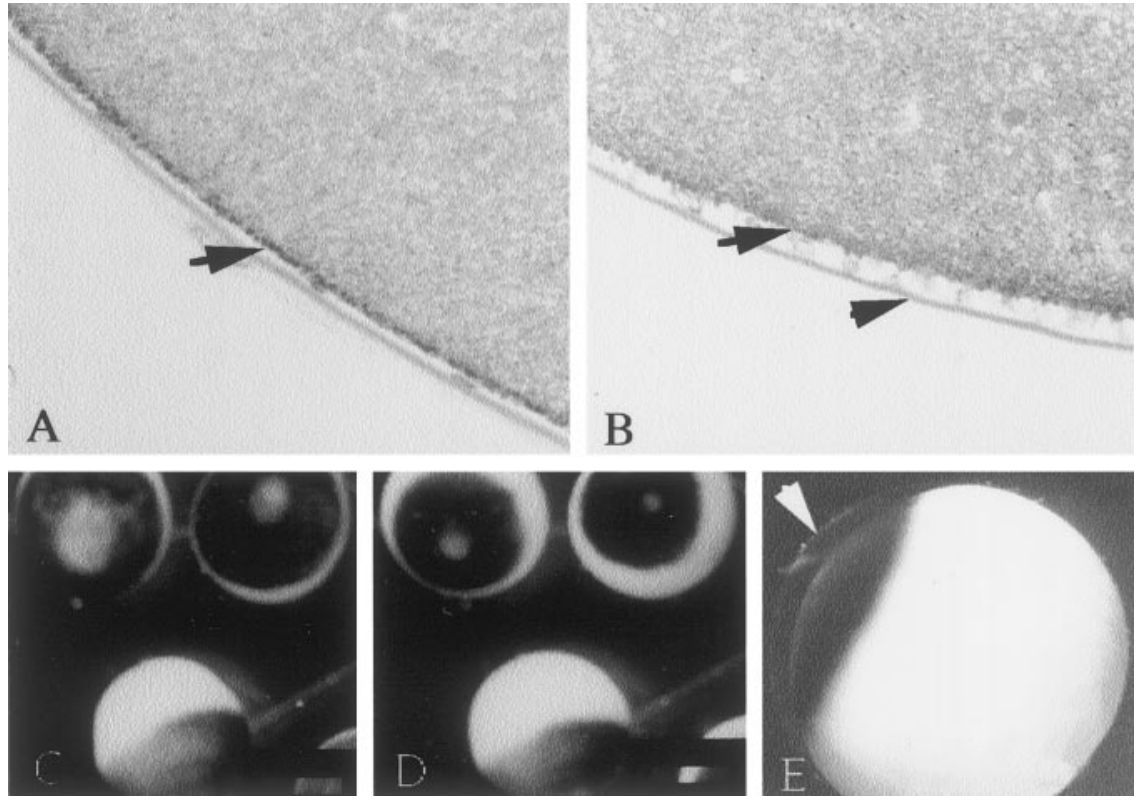

FIG. 4. Changes observed as Xenopus eggs expressing GalT-I are activated. Eggs were sectioned and cortical granules stained with periodic acid-Schiffs reagent (PAS). (A) Control egg injected with water and treated with GalT-I antibodies. Cortical granules are evident just under the plasma membrane, labeled with an arrow. (B) GalT-I-expressing egg treated with GalT-I antibody showing release of cortical granules. The arrow shows the exocytosis of cortical granules. The vitelline envelope has separated from the plasma membrane, as shown by the arrowhead. (C) Eggs expressing GalT-I prior to addition of GalT-I antibody. (D) The same eggs as in (C) 10 minutes after addition of GalT-I antibody showed contraction of the pigmented zone of the animal pole. (E) GalT-Iexpressing egg treated with GalT-I antibody illustrating the elevation of the vitelline envelope, shown by the arrow. [Adapted with permission from Shi X, Amindari S, Paruchuru K, Skalla D, Burkin H, Shur BD, Miller DJ 2001 Cell surface $\beta$-1,4-galactosyltransferase-I activates G protein-dependent exocytotic signaling. Development 128:645-654. Copyright Company of Biologists, Ltd.]

Studies of the first two examples and mastoparan, a peptide that activates $\mathrm{G}_{\mathrm{i}}$ and $\mathrm{G}_{\mathrm{o}}$ proteins, have led to a proposed structural motif (Okamoto et al., 1990; Nishimoto et al., 1993). The minimal motif is from 14-23 amino acids long and contains two basic amino acids near the $\mathrm{N}$-terminus and the sequence BBXB or $\mathrm{BBXXB}$ near the $\mathrm{C}$-terminus, where $\mathrm{B}$ is a basic residue and $\mathrm{X}$ is any residue. More recent studies have identified similar clusters of basic domains in traditional seven transmembrane-spanning receptors that are necessary for $\mathrm{G}$ protein activation (Lee et al., 1996; Xie et al., 1997; Frandberg et al., 1998; Wade et al., 1999; Wang, 1999). The cytoplasmic domain of long GalT-I is 24 amino acids in length and has clusters of basic residues at each end of the cytoplasmic 
A

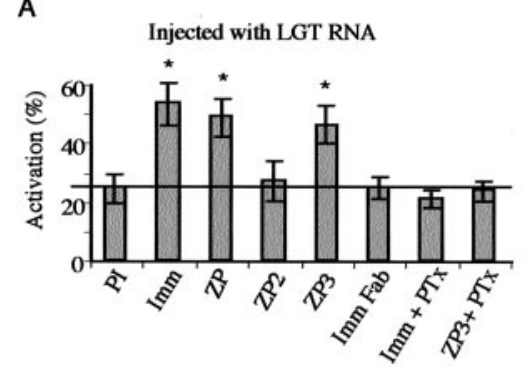

C

Injected with SGT RNA

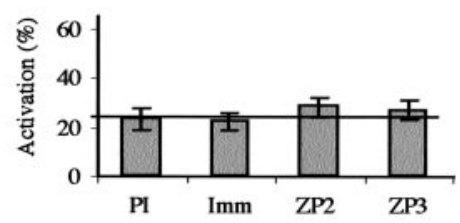

B

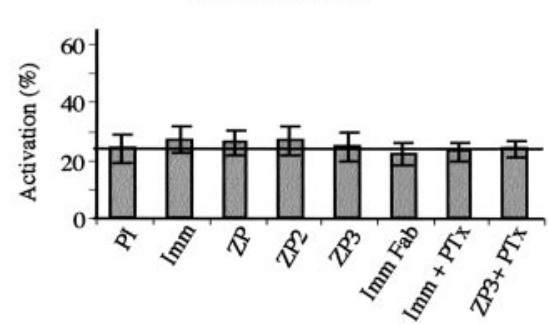

D

Injected with $\triangle$ LGT RNA

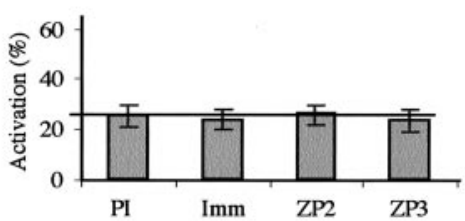

FIG. 5. GalT-I agonists activated Xenopus eggs expressing long GalT-I. (A) Addition of total zona pellucida (ZP) glycoproteins, ZP3, or GalT-I antibodies (Imm) to eggs expressing GalT-I triggered cortical granule exocytosis, cortical contraction, and vitelline envelope elevation. Ligands were added to GalT-I-expressing eggs and signs of activation were observed for 20 minutes. GalT-Iexpressing eggs treated with preimmune antibodies $(\mathrm{PI})$, monovalent $\mathrm{F}_{\mathrm{ab}}$ fragments $\left(\mathrm{Imm} \mathrm{F}_{\mathrm{ab}}\right.$ ) or ZP2 had background activation rates. Pertussis toxin (PTx) pretreatment of eggs prevented activation. (B) Eggs injected with water had low activation rates. (C) Eggs expressing the short GalT-I protein (SGT) or (D) expressing long GalT-I with a mutation in the putative G protein activation domain ( $\Delta$ LGT) did not activate in response to agonists. An asterisk above the bars indicates a significant difference from the groups without an asterisk $(P<0.01)$. [Adapted with permission from Shi $\mathrm{X}$, Amindari $\mathrm{S}$, Paruchuru K, Skalla D, Burkin H, Shur BD, Miller DJ 2001 Cell surface $\beta$-1,4-galactosyltransferase-I activates $G$ protein-dependent exocytotic signaling. Development 128:645-654. Copyright Company of Biologists, Ltd.]

sequence. The cytoplasmic domain of short GalT-I is only 11 amino acids and lacks the N-terminal cluster of basic residues. Short GalT-I was unable to activate $\mathrm{G}$ proteins and exocytosis when expressed in oocytes (Figures 5 and 6). Therefore, we mutated the two arginine residues near the N-terminus found only in the long form and expressed this mutant in oocytes. The mutant did not activate $\mathrm{G}$ proteins and did not activate oocytes or trigger the release of cortical granules (Figures 5 and 6; Shi et al., 2001). This suggests that GalT-I may interact with $\mathrm{G}$ proteins using motifs related to those found in seven transmembrane receptors that interact with $\mathrm{G}$ proteins. 
A

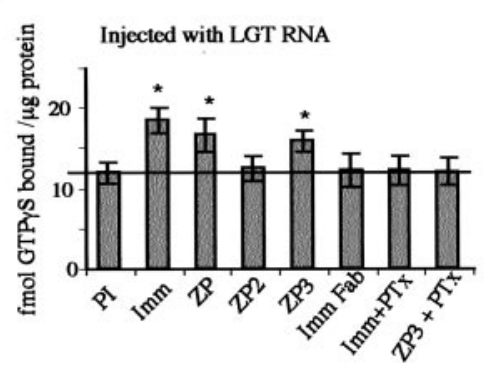

C

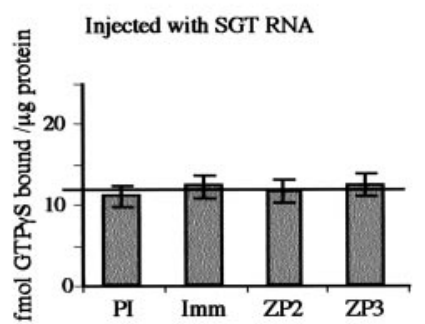

B

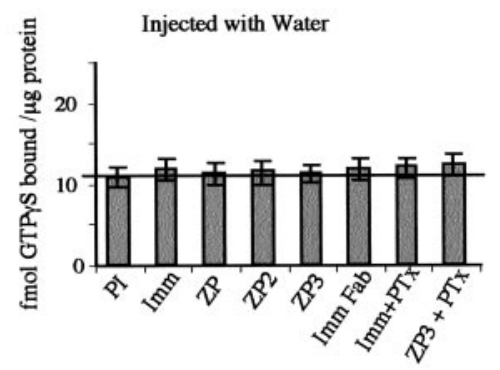

D

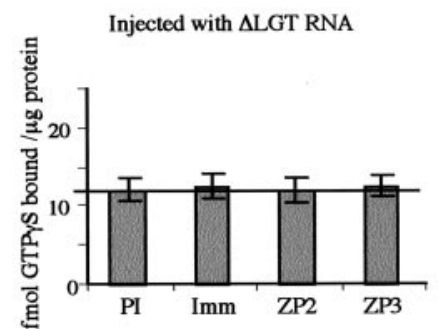

FIG. 6. GalT-I agonists increase GTP $\gamma\left[{ }^{35} \mathrm{~S}\right]$ binding to membranes from Xenopus oocytes expressing long GalT-I. (A) Addition of total zona pellucida (ZP) glycoproteins, ZP3, or GalT-I antibodies (Imm) to eggs expressing GalT-I increased GTP $\gamma\left[{ }^{35} \mathrm{~S}\right]$ binding. Addition of preimmune antibodies (PI), monovalent $\mathrm{F}_{\mathrm{ab}}$ fragments $\left(\operatorname{Imm} \mathrm{F}_{\mathrm{ab}}\right.$ ) or ZP2 activated only background levels of GTP $\gamma\left[{ }^{35} \mathrm{~S}\right]$ binding. Pertussis toxin (PTx) pretreatment of eggs prevented any change in GTP $\gamma\left[{ }^{35} \mathrm{~S}\right]$ binding in response to GalT-I agonists. (B) Membranes from water-injected control eggs showed no change in GTP $\gamma\left[{ }^{35} \mathrm{~S}\right]$ binding. (C) Eggs expressing the short GalT-I protein or (D) eggs expressing long GalT-I with a mutation in the putative G protein-binding domain did not respond to GalT-I agonists. An asterisk above the bars indicates a significant difference from the groups without an asterisk $(P<0.05)$. [Adapted with permission from Shi X, Amindari S, Paruchuru K, Skalla D, Burkin H, Shur BD, Miller DJ 2001 Cell surface $\beta$-1,4-galactosyltransferase-I activates G proteindependent exocytotic signaling. Development 128:645-654. Copyright Company of Biologists, Ltd.]

If GalT-I signaling proceeds through $G$ protein activation, there may be a direct interaction between GalT-I and a specific G protein complex. Alternately, GalT-I could bind to a type of adapter protein that could, in subsequent steps, activate $\mathrm{G}$ proteins. Therefore, it was important to determine whether there was a protein-protein connection between GalT-I and G proteins. The sequence corresponding to the long form of the GalT-I cytoplasmic domain was coupled to Sepharose and used to precipitate proteins that associated with the long form of GalT-I. Both $\mathrm{G}_{\mathrm{i} \alpha}$ and $\mathrm{G}_{\beta \gamma}$ were precipitated with GalT-I (Gong et al., 1995). 


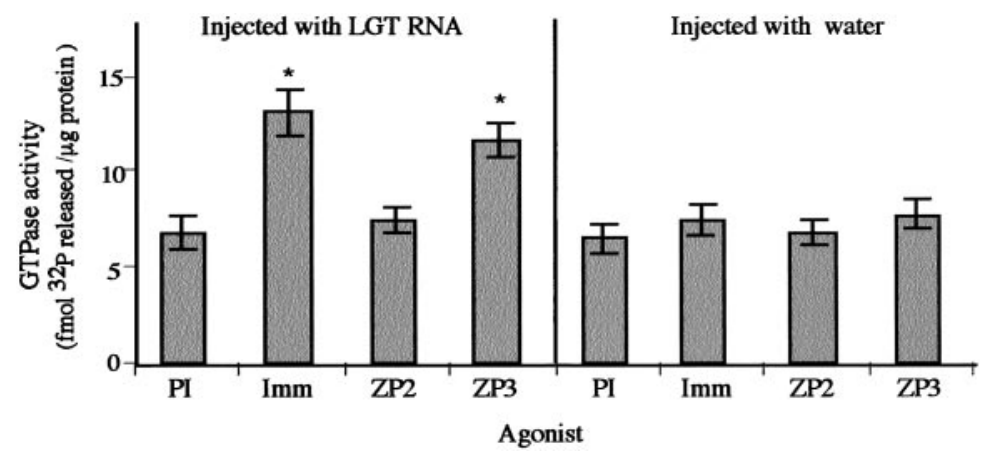

FIG. 7. Addition of ZP3 or GalT-I antibodies (Imm) to eggs expressing GalT-I increased GTP hydrolysis. Preimmune antibodies (PI) or ZP2 stimulated only background levels of GTPase activity (left panel). Control eggs injected with water did not respond to GalT-I agonists (right panel). An asterisk above the bars indicates a significant difference from the groups without an asterisk $(P<$ 0.05). [Adapted with permission from Shi X, Amindari S, Paruchuru K, Skalla D, Burkin H, Shur BD, Miller DJ 2001 Cell surface $\beta$-1,4-galactosyltransferase-I activates $\mathrm{G}$ protein-dependent exocytotic signaling. Development 128:645-654. Copyright Company of Biologists, Ltd.]

This demonstrated that $\mathrm{G}$ proteins could form complexes with the GalT-I cytoplasmic domain but, unfortunately, this technique does not identify the specific protein-protein interactions. A valuable approach to identify protein partners that interact directly is the yeast two-hybrid system. Among several proteins identified as GalT-I binding partners using the yeast two-hybrid system is a protein called SSeCKS (Wassler et al., 2001). SSeCKS is expressed in the testis and found on the periacrosomal area of mature sperm, the same region as GalT-I (Erlichman et al., 1999; Nixon et al., 2001). Immunoprecipitation studies confirmed that GalT-I interacts with SSeCKS (Wassler et al., 2001). SSeCKS is particularly interesting because it can serve as an anchoring protein for both protein kinase $\mathrm{A}$ and $\mathrm{C}$ and may thereby regulate signal transduction (Lin et al., 1996; Erlichman et al., 1999).

\section{Signal Transduction Steps During the Acrosome Reaction}

The sequence of events that triggers the acrosome reaction is not certain but some pieces are starting to fit together into a model. The target of the activated $\mathrm{G}$ proteins is not clear. Members of the phospholipase $\mathrm{C}$ family are frequent targets of $\mathrm{G}$ proteins. It is intriguing that targeted deletion of one phospholipase $\mathrm{C} \delta$ isoform (PLC $\delta 4)$ reduces male fertility and fertilization rates (Fukami et al., 2001). The effect on fertility was apparently related to the inability of sperm to release the acrosome in response to binding the zona pellucida. Whether PLC $\delta 4$ is activated by $\mathrm{G}$ proteins or some other mechanism is unknown. Other phos- 
pholipase C isoforms are present in sperm (Walensky and Snyder, 1995). How any PLC isoform is activated in sperm is unclear because of the gaps in our knowledge of signaling through ZP3 receptors. Inositol 1,4,5-trisphosphate (IP3) produced by PLC can bind to and activate IP3 receptors on the acrosome (Walensky and Snyder, 1995). Release of calcium from the acrosome depletes the internal stores of calcium, activating store-operated calcium channels and allowing calcium influx. The store-operated channels include the protein Trp2 and perhaps other Trp proteins (Jungnickel et al., 2001). Additionally, ZP3 binding triggers membrane depolarization and a transient influx of calcium through what behave as low-voltage-activated T-type calcium channels that are regulated by capacitation (Arnoult et al., 1999). The increase in intracellular calcium is necessary for docking and fusion of the outer acrosomal and plasma membranes during acrosomal exocytosis. Membrane fusion appears to include SNAREs, Rab3A, and other molecules involved with membrane fusion in somatic cells (Schulz et al., 1997; Iida et al., 1999; Ramalho-Santos et al., 2000).

\section{Genetic Modulation of GalT-I Activity in Mouse Sperm}

Studies of transgenic mice with elevated or absent GalT-I enzyme activity have provided considerable insight into the function of GalT-I. As expected, sperm from mice that overexpress GalT-I bind greater amounts of purified soluble ZP3 (Youakim et al., 1994b). Unexpected was the observation that sperm with high GalT-I activity were less able to bind to oocytes (Youakim et al., 1994b). This appears to reflect two different phenomena. First, sperm with increased GalT-I either bind more glycosides from epididymal fluid or bind them with higher affinity. These glycosides often are referred to as decapacitation factors because they block sperm capacitation and fertilization (Yanagimachi, 1994). After removing these glycosides, more sperm are able to bind the zona pellucida. The second causative phenomenon is that sperm with increased GalT-I undergo precocious acrosome reactions. Sperm overexpressing GalT-I undergo greater zona-induced $\mathrm{G}$ protein activation, more rapid acrosome reactions, but bind more tenuously to the zona pellucida (Youakim et al., 1994b). It appears that acrosome-reacted sperm have lower affinity for the zona pellucida because free-swimming, acrosome-reacted mouse sperm do not initiate binding to the zona (Florman and Storey, 1982). Therefore, the most likely explanation of the lower affinity binding to the zona pellucida of GalT-I transgenic sperm is that they have undergone the acrosome reaction very quickly and are removed when the oocytes are washed to remove sperm bound by low affinity.

Targeted disruption of GalT-I from mouse sperm yielded intriguing results. Most animals with disruption of both long and short forms of GalT-I die perinatally but the males that survive produce sperm with negligible levels of GalT activity (Lu and Shur, 1997). Sperm from GalT-I null mice bind a reduced 
amount of purified soluble ZP3 and their ability to undergo the zona-induced acrosome reaction is severely compromised. The defect appears relatively specific, as sperm still can undergo the acrosome reaction in response to calcium ionophore, which bypasses the ZP3-binding step. As a result of the defect in the acrosome reaction, GalT-I null sperm show flawed penetration of the zona pellucida (Lu and Shur, 1997). Surprisingly, sperm showed no decrease in binding to the intact zona pellucida. The reason binding to the intact zona is not affected is perhaps that ZP3 in the zona is modified by oviduct fluid. Purified ZP3 usually is collected from oocytes that have not been exposed to oviduct fluid. In view of the zona penetration defect in vitro, also unforeseen was that there was no obvious defect in male fertility in vivo in GalT-I null sperm (Asano et al., 1997; Lu and Shur, 1997; Lu et al., 1997). Perhaps some compensatory mechanisms exist in vivo that overcome the defect. Alternately, similar to the results with acrosin-null mice, the defect in GalT-I null sperm may be more subtle in vivo. Carefully designed assays may detect a delay or a competitive disadvantage when GalT-I null sperm are compared to wild-type sperm.

Elimination of both long and short forms of GalT-I may have global effects on glycoprotein processing in the Golgi and thereby affect sperm fertility. To minimize alterations in glycosylation, the long form of GalT-I was selectively disrupted. Sperm lacking the long isoform still have GalT activity, reflecting enzyme synthesized from the short transcript, and protein glycosylation appears normal (Lu and Shur, 1997). But these sperm are unresponsive to ZP3. Thus, the fertilization defects in long GalT-I null sperm are not due to disruption of protein glycosylation. Furthermore, the short form of GalT-I is not able to activate signal transduction; the longer cytoplasmic domain is required for normal signal transduction. This is consistent with results from expressing both forms in Xenopus oocytes. Only the long form is able to activate $\mathrm{G}$ proteins and trigger exocytotic signaling when expressed on Xenopus oocytes (Shi et al., 2001).

Considering that sperm from GalT-I null mice are still able to bind to oocytes and that GalT-I null males are fertile, other zona receptors must be capable of serving as adhesion molecules during sperm-zona binding. Other receptors may impart species specificity to gamete recognition. Sea urchins and abalone provide some insight to the problem of species specificity. In abalone, a sperm protein called lysin creates a hole in the egg coat, known as the vitelline envelope (Swanson and Vacquier, 1998). Regions within lysin show divergence between species and some of these divergent segments impart species specificity (Lyon and Vacquier, 1999). Similarly, the sea urchin sperm protein bindin is polymorphic at distinct regions within the molecule. Even females within a species indicate a preference for sperm carrying specific bindin genotypes (Palumbi, 1999). In female mammals, there are corresponding divergent regions in $\mathrm{ZP} 2$ and $\mathrm{ZP} 3$ that are under positive selection. Some divergent regions are found in the region in which the sperm-binding oligosaccharides are attached 
(Swanson et al., 2001). No specific segment of GalT-I has been identified that is hypervariable between species. Furthermore, in addition to GalT-I, porcine sperm have other redundant zona receptors, as described earlier (Rebeiz and Miller, 1999). Therefore, a reasonable model is that the role of GalT-I is to cooperate with other zona receptors that have divergent segments that could contribute towards the species-restricted nature of gamete binding. Based on the knockout results, the more necessary role of GalT-I appears to be signaling to trigger the acrosome reaction. The identity of receptors that cooperate with GalT-I in a putative complex is unknown.

\section{Zona Penetration}

During the acrosome reaction, sperm remain bound to the zona pellucida, perhaps through the interaction of acrosomal proteins that bind ZP3 such as sp56 (Kim et al., 2001a,b). After the acrosome has completely dispersed, sperm lose affinity for ZP3 and gain affinity for ZP2 (Bleil and Wassarman, 1986; Mortillo and Wassarman, 1991). The interaction with ZP2 apparently retains sperm on the zona pellucida so that the sperm can begin penetration through the zona. Penetration may involve enzymatic hydrolysis of the zona pellucida but also requires the forward physical force of sperm motility (Bedford, 1998). Although the acrosomal protease acrosin is not required, other acrosomal proteases may be important for zona penetration. But the sea abalone egg coat is dissolved without hydrolysis by the lysin from sperm (Swanson and Vacquier, 1997). Whether zona pellucida penetration absolutely requires lysis of zona proteins is uncertain.

\section{Sperm Binding and Fusion with the Oocyte Plasma Membrane}

After zona penetration, sperm attach to the oocyte plasma membrane and the two cells fuse together. A number of studies suggest that ADAM family members bind to integrin receptors on oocytes. The ADAM family members most heavily implicated are two found in the fertilin dimer (fertilin $\alpha$ or ADAM- 1 and fertilin $\beta$ or ADAM-2) and cyritestin (ADAM-3). Synthetic peptides corresponding to specific fertilin $\beta$ and cyritestin sequences inhibit sperm binding and fusion to the oocyte plasma membrane (Myles et al., 1994; Evans et al., 1995; Yuan et al., 1997). Recombinant proteins containing portions of ADAM members and corresponding antibodies also inhibit sperm binding and fusion (Almeida et al., 1995; Evans et al., 1997; Bigler et al., 2000; Takahashi et al., 2001). The role of fertilin $\alpha$ may be unique. Fertilin $\alpha$ has a hydrophobic peptide sequence that resembles fusion peptides found in viral proteins and it has been proposed to mediate sperm fusion with the oocyte membrane (Martin et al., 1998; Wolfe et al., 1999). 
Results using mice with specific deletions of fertilin $\beta$ or cyritestin yielded surprising results. Fertilin $\beta$-null mice are infertile. Their sperm fail to adhere to the egg plasma membrane (13\% of wild-type level) and have reduced ability to fuse with oocytes (45-50\% of wild-type level), although some fusion occurs (Cho et al., 1998). What is surprising is that sperm from fertilin $\beta$-null mice also have defects in sperm migration from the uterus into the oviduct and in binding to the zona pellucida. Cyritestin -/- sperm have reduced zona and egg membrane binding but these defects did not affect fusion with the oocyte membrane and fertilization (Nishimura et al., 2001). Both knockouts cause a reduction in abundance of other proteins on sperm, including fertilin $\alpha$ (Nishimura et al., 2001). The effects of deleting these genes on sperm migration through the reproductive tract and on zona binding could be caused by defects in transport of proteins to the sperm plasma membrane or on their function at the plasma membrane.

The protein partner on oocytes to which fertilin $\beta$ binds was believed to be $\alpha 6 \beta 1$ integrin (Almeida et al., 1995). Antibodies to $\alpha 6$ blocked binding of sperm, although this appeared to depend on the conditions used (Almeida et al., 1995; Evans et al., 1997). More recently, it was discovered that oocytes lacking $\alpha 6$ are still able to bind and fuse with sperm (Miller et al., 2000). Perhaps other integrins that are reported to bind ADAM family members are found on oocytes and could fulfill that function. In contrast, a protein on oocytes called CD9, a member of the tetraspanin family of proteins (four transmembrane domains), is necessary for sperm fusion. CD9 associates with $\beta 1$ integrins and antibodies to CD9 inhibit sperm-oocyte binding and fusion (Chen et al., 1999). Oocytes from mice with targeted deletion of CD9 bind sperm normally but are defective in sperm fusion (Kaji et al., 2000; Le Naour et al., 2000; Miyado et al., 2000). $\beta 1$ integrin associates with other tetraspanins, including CD81 and CD98. Antibodies to both these tetraspanins inhibit fertilization (Takahashi et al., 2001). It has been proposed that a web of ADAMs and multiple $\beta 1$ integrin-associated proteins are formed to mediate sperm-oocyte membrane interactions (Takahashi et al., 2001). In fact, the tetraspanins, integrins, and ADAM family members include a large number of proteins and several are present on gametes (Evans, 2001). Dissecting their individual functions will be challenging.

\section{Egg Activation and the Block to Polyspermic Zona Binding}

After sperm bind and fuse with the oocyte plasma membrane, the oocyte is "reawakened," a process referred to as activation. One of the earliest hallmarks of this activation is a release of calcium from intracellular stores (Stricker, 1999; Carroll, 2001). There is considerable debate about what triggers activation but there is accumulating evidence in mammals that a sperm component released at fusion can activate a series of calcium transients and trigger development (Perry 
et al., 2000; Wu et al., 2001). As eggs are activated, the cortical granules are released and their secretions act on the zona pellucida. Following cortical granule release, the zona pellucida loses its ability to bind sperm and bound sperm cease penetration through the zona. ZP3 purified from fertilized eggs is inactive; it does not competitively inhibit sperm binding to unfertilized oocytes, although no change in behavior on SDS-PAGE is detectable (Bleil and Wassarman, 1980). In contrast, ZP2 is cleaved by an unidentified protease released at egg activation (Moller and Wassarman, 1989).

We found that ZP3 from fertilized eggs loses its ability to bind sperm GalT-I. This is due to secretion of hexosaminidase from the cortical granules. Hexosaminidase B is found abundantly in cortical granules of mouse and Xenopus oocytes (Miller et al., 1993; Greve et al., 1985). As oocytes are activated, it removes specific $\mathrm{N}$-acetylglucosamine residues from ZP3 so that ZP3 does not bind additional sperm (Miller et al., 1993). If this hexosaminidase is blocked with specific inhibitors of $\mathrm{N}$-acetylglucosaminidase or antibodies during egg activation, multiple sperm bind to activated eggs (Miller et al., 1993).

\section{Fertilization in Other Mammals}

\section{A. FUNCTION OF ZONA PELLUCIDA RECEPTORS ON PORCINE AND BOVINE SPERM}

Although the mouse has been the most studied mammal, there is considerable information about the molecular biology of fertilization in the pig. One reason it has been a popular animal is that large numbers of porcine gametes can be acquired. Studies of the porcine zona pellucida have been hampered by the inability to purify zona proteins without denaturing and deglycosylating the glycoproteins and perhaps affecting their biological activity. After partial deglycosylation, a mixture of porcine ZP1 and ZP3 appear most effective in binding sperm. Perhaps a heterodimer of these two zona glycoproteins is necessary for binding porcine sperm (Yurewicz et al., 1998).

Several candidate zona receptors on porcine sperm have been identified and discussed earlier in this review. GalT-I has been identified on a number of mammalian sperm, including that from rabbits, horses, cattle, rats, guinea pigs, and domestic pigs (Larson and Miller, 1997). Its location has been studied on cattle and porcine sperm, where it is found on the plasma membrane overlying the acrosomal region of sperm (Fayrer-Hosken et al., 1991; Larson and Miller, 1997; Tengowski et al., 2001). Antibodies to GalT-I inhibit sperm-zona binding and fertilization of bovine oocytes (Tengowski et al., 2001). Studies of porcine fertilization have yielded intriguing results. To determine if GalT-I bound the porcine zona pellucida, porcine sperm were incubated with soluble whole zona proteins and the sugar donor, uridine-diphospho- $\left[{ }^{3} \mathrm{H}\right]$-galactose. In this experi- 
ment, the zona proteins bound to GalT-I would be labeled by $\left[{ }^{3} \mathrm{H}\right]$-galactose. The labeled galactose was attached to porcine zona proteins with a broad range in molecular weights from $50-75 \mathrm{kDa}$, the region in which ZP1 and ZP3 migrate (Rebeiz and Miller, 1999). Therefore, either one or both are ligands for porcine sperm GalT-I. But, surprisingly, reagents that blocked GalT-I or its zona ligand did not inhibit porcine sperm-zona binding (Rebeiz and Miller, 1999). These results suggested that GalT-I is a redundant zona receptor in the domestic pig.

Since GalT-I appeared to be a redundant zona receptor in porcine fertilization, it was important to ascertain its specific role as part of a zona receptor complex. It was important to determine if GalT-I, by itself, was sufficient to bind sperm to the zona pellucida. To answer this question, we removed the GalT-I binding sites from soluble porcine zona proteins using hexosaminidase. These enzyme-treated zona proteins could bind to other receptors on sperm but not to GalT-I. When the enzyme-treated zona proteins were added to sperm, leaving only GalT-I exposed, these sperm were unable to bind to oocytes (Rebeiz and Miller, 1999). Therefore, GalT-I on porcine sperm is not sufficient to bind sperm to the zona pellucida (Figure 8). GalT-I can bind soluble zona proteins but perhaps the affinity for zona proteins is inadequate for GalT-I to hold a highly motile sperm on the zona pellucida.

\section{B. LOCALIZATION OF ZONA RECEPTORS ON PORCINE SPERM}

When assessing the functional role of candidate zona receptors, one important criterion is that the protein be localized to the region of sperm that binds the zona pellucida. ZP3 binds to acrosome-intact but not acrosome-reacted mouse sperm. The precise region of mouse sperm that binds ZP3 was examined using gold-labeled ZP3 (Mortillo and Wassarman, 1991). Gold particles were bound throughout the head of acrosome-intact sperm. Gold-labeled ZP2 bound to the postacrosomal region of acrosome-intact sperm and to the inner acrosomal membrane of acrosome-reacted sperm. The region of sperm from other mammals that bound zona proteins has been controversial.

To resolve this issue on porcine sperm, we directly labeled soluble total zona proteins with Alexa, an intense fluorescent probe, and incubated them with sperm (Burkin and Miller, 2000). Labeled zona proteins retained normal biological activity, assessed by inhibition of sperm binding to oocytes and by induction of the acrosome reaction (Burkin and Miller, 2000). Dead sperm were identified by labeling with propidium iodide. Zona proteins bound primarily to the apical edge of the plasma membrane covering the acrosome of sperm (Figure 9A\&B). Labeled control proteins did not bind sperm and binding of zona proteins was eliminated by an excess of unlabeled zona proteins (Figure 9C-F). After induction of the acrosome reaction, zona proteins bound to a larger portion of the sperm head, to the anterior half of sperm (Figure 10A). The time course of the 

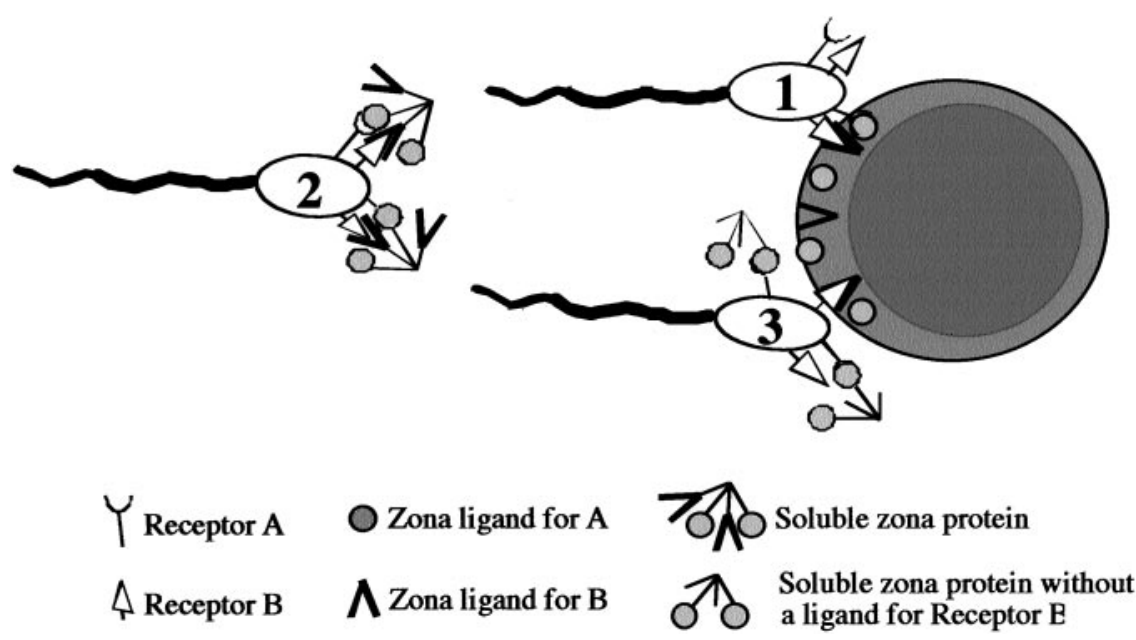

FIG. 8. Schematic drawing of experiment to determine the importance of redundant receptors. When performing competitive binding assays, one can determine if a single receptor in a redundant system is adequate to allow gamete binding. Suppose there are two receptors on the surface of the porcine spermatozoa named A and B (B represents GalT-I in our experiments). Normally, A and B are both able to bind their individual ligands on the porcine zona pellucida, allowing normal sperm-zona attachment (Sperm \#1). If soluble zona is added, both A and B will bind their respective ligands on the soluble zona pellucida and sperm egg binding will be decreased (Sperm \#2). If an enzyme able to cleave the ligand for receptor B is used to digest soluble zona, the result is soluble zona deficient in the ligand for $\mathrm{B}$. These soluble zona will inhibit the action of A but, because they cannot compete for the binding of receptor B, B is free to bind its ligand on the intact oocyte zona pellucida (Sperm \#3). Using this approach, it can be determined if B alone is sufficient to mediate sperm-zona binding.

acrosome reaction matched the change in zona binding pattern (Figure 10B). It also appeared that more total zona protein was bound to sperm following the acrosome reaction. Based on these results, we expect to find primary zona receptor candidates on the apical ridge of acrosome-intact sperm. Secondary zona receptor candidates on acrosome-reacted sperm are expected to be found over the entire acrosomal region.

Although zona receptors were detected on porcine ejaculated sperm, the maturational stage at which sperm acquired the ability to bind zona proteins was controversial. We collected sperm from the caput, corpus, and cauda epididymis and incubated these sperm with labeled zona proteins (Figure 11). Whereas 6\% of the caput sperm bound zona proteins, $75 \%$ and $93 \%$ of the corpus and cauda sperm, respectively, bound zona proteins in the same localization pattern as ejaculated sperm (Burkin and Miller, 2000). Therefore, it appears that either zona receptors already on sperm are transformed into an active state or that sperm acquire zona-binding proteins as they pass through the epididymis. 


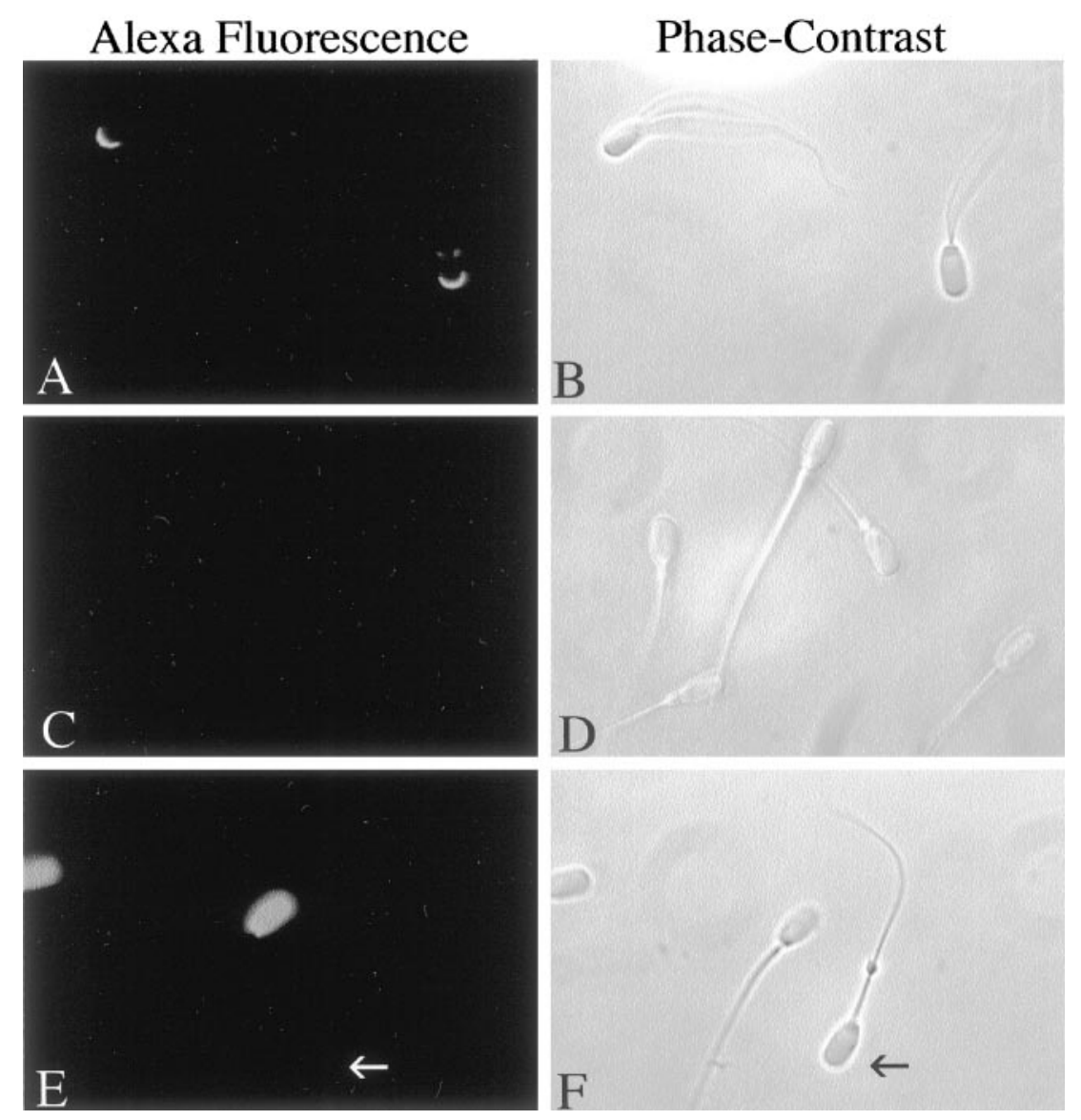

FIG. 9. Localization of solubilized zona pellucida proteins on live sperm. Alexa-labeled zona proteins and propidium iodide were added to live boar sperm. Alexa-zona proteins bound live, acrosomeintact sperm over the anterior head region concentrated over the acrosomal ridge (A). Addition of a 100 -fold excess of unlabeled zona proteins displaced the signal (C). The Alexa-labeled control glycoprotein, transferrin, did not bind to live sperm indicated by the arrow in (E). Dead sperm stained with propidium iodide over the entire head are visible, since fluorescence images were captured using a filter set that allowed detection of both red and green fluorochromes simultaneously (A,C,E). Corresponding phase-contrast images are shown (B,D,F). [Adapted with permission from Burkin HR, Miller DJ 2000 Zona pellucida protein binding ability of porcine sperm during epididymal maturation and the acrosome reaction. Dev Biol 222:99-109. Copyright Academic Press.]

\section{Conclusions}

Despite 20 years of investigation, the molecular basis underlying fertilization remains an enigma. Although the role of ZP3 in mouse fertilization is well 


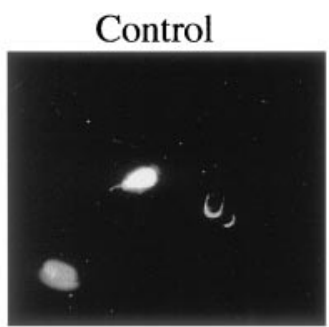

\section{Ionophore}
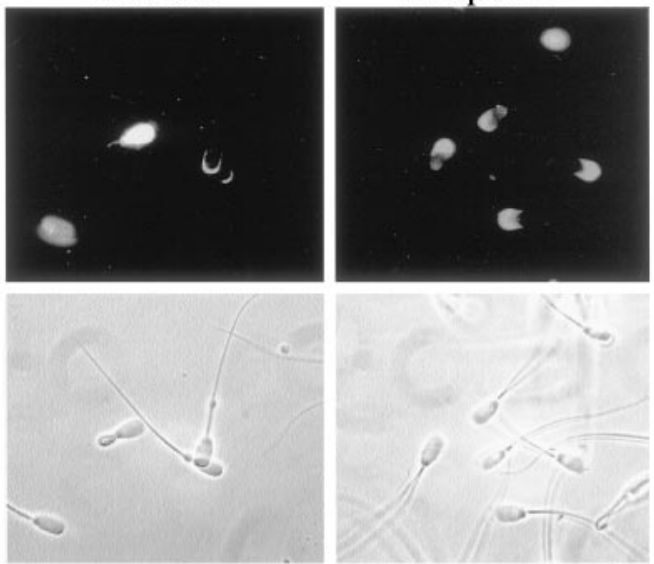

B

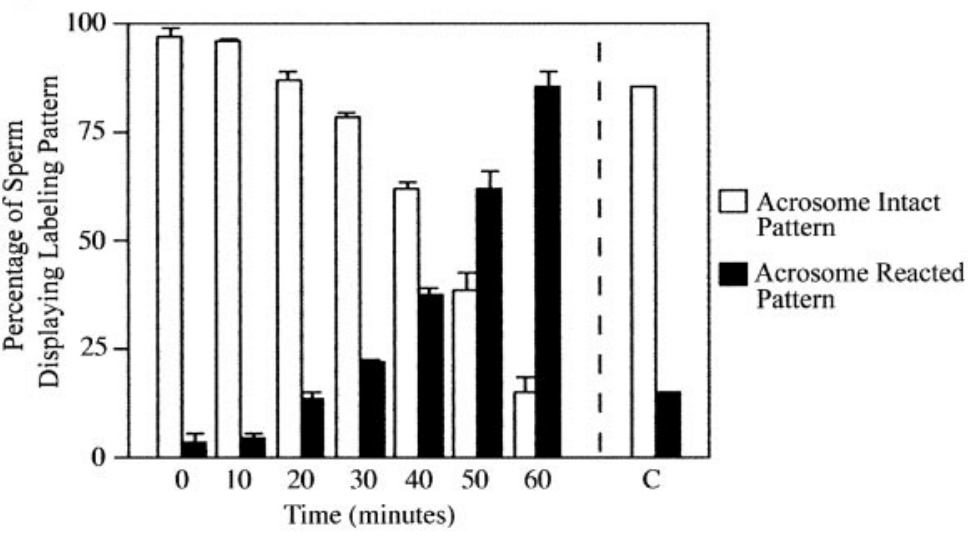

FIG. 10. Binding of zona pellucida proteins is increased in acrosome-reacted sperm. Live, capacitated boar sperm were incubated with the calcium ionophore A23187 to induce the acrosome reaction, followed by the addition of Alexa-zona proteins and propidium iodide. The upper panels in (A) show fluorescence images of Alexa-zona and propidium iodide, the lower panels show corresponding phase-contrast images. Acrosome-reacted sperm showed an increased area of zona protein binding, extending from the acrosomal ridge to the equatorial region of live sperm, whereas controls without ionophore did not. Intense sperm head staining in the left panel and light staining at the base of the head in the right panel are due to propidium iodide. For time course experiments (B), samples were removed and at least 200 sperm counted at 10-minute intervals after the addition of ionophore. The percentage of live sperm displaying zona binding in a thin band over the acrosomal ridge decreased with time (white bars), while the percentage displaying strong acrosomal fluorescence increased (black bars). Controls to which ionophore was not added ("C") were counted after 60 minutes. [Adapted with permission from Burkin HR, Miller DJ 2000 Zona pellucida protein binding ability of porcine sperm during epididymal maturation and the acrosome reaction. Dev Biol 222:99-109. Copyright Academic Press.] 

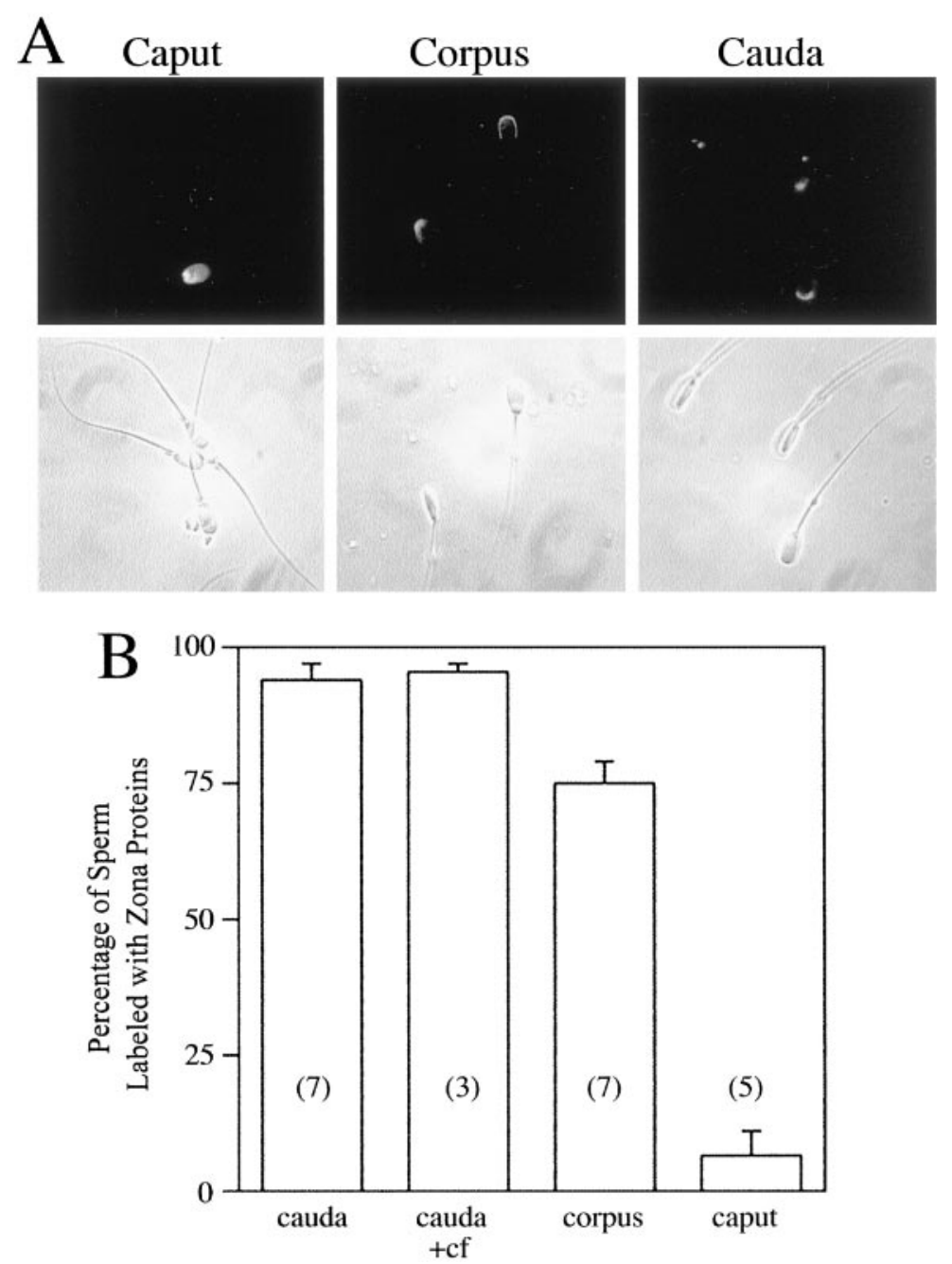

FIG. 11. Boar sperm acquire the ability to bind zona pellucida proteins during epididymal maturation. Sperm from the caput, corpus, and cauda regions of the boar epididymis were capacitated and incubated with Alexa-zona proteins and propidium iodide. (A) Most caput sperm do not bind zona proteins. Those that do display a very faint signal. The intensely labeled sperm is labeled with propidium iodide. In contrast, most corpus and cauda sperm exhibit intense zona protein binding. (B) Quantitation of live, acrosome-intact sperm displaying zona fluorescence. Approximately $93 \%$ of cauda sperm and $75 \%$ of corpus sperm bound zona proteins. In contrast, only about $6.4 \%$ of caput sperm bind zona proteins after extensive washing. Ninety-five percent of cauda sperm incubated for 4 hours in caput fluid $(+\mathrm{cf})$ retained the ability to bind zona proteins. [Adapted with permission from Burkin HR, Miller DJ 2000 Zona pellucida protein binding ability of porcine sperm during epididymal maturation and the acrosome reaction. Dev Biol 222:99-109. Copyright Academic Press.] 
established, there is debate about its role in other species. ZP3 is glycosylated variably between species and it seems apparent that how ZP3 is glycosylated will impact the species specificity of sperm binding. There are a number of candidate $\mathrm{ZP} 3$ receptors whose function is still unclear. GalT-I is the ZP3 receptor that has been studied in most detail. Recent evidence suggests its role is more necessary in signal transduction leading to the acrosome reaction than in initial ZP3 binding. After zona penetration, members of the ADAM, integrin, and tetraspanin family may form a complex, allowing sperm to fuse with the oocyte plasma membrane and activate development. Further studies of GalT-I knockout mice as well as knockouts of ADAM, integrin, and tetraspanin members should provide valuable clues about the molecular biology of gamete interaction. The enhanced ability to identify important genes and then to delete them from the animal genome offers opportunities to assemble the puzzle and solve the complicated process of mammalian fertilization.

\section{ACKNOWLEDGMENTS}

Research in the author's laboratory was supported by the National Institutes of Health, the National Science Foundation, the U.S. Department of Agriculture, the University of Illinois Agricultural Experiment Station, and the Illinois Council for Food and Agricultural Research. The authors thank the members of the Miller laboratory for careful review of the manuscript and for creative and critical review of the original research.

\section{REFERENCES}

Adham IM, Nayernia K, Engel W 1997 Spermatozoa lacking acrosin protein show delayed fertilization. Mol Reprod Dev 46:370-376

Almeida EA, Huovila AP, Sutherland AE, Stephens LE, Calarco PG, Shaw LM, Mercurio AM, Sonnenberg A, Primakoff P, Myles DG 1995 Mouse egg integrin $\alpha 6 \beta 1$ functions as a sperm receptor. Cell 81:1095-1104

Amado M, Almeida R, Schwientek T, Clausen H 1999 Identification and characterization of large galactosyltransferase gene families: galactosyltransferases for all functions. Biochim Biophys Acta 1473:35-53

Arnoult C, Kazam IG, Visconti PE, Kopf GS, Villaz M, Florman HM 1999 Control of the low voltage-activated calcium channel of mouse sperm by egg ZP3 and by membrane hyperpolarization during capacitation. Proc Natl Acad Sci USA 96:6757-6762

Asano M, Furukawa K, Kido M, Matsumoto S, Umesaki Y, Kochibe N, Iwakura Y 1997 Growth retardation and early death of $\beta 1,4$-galactosyltransferase knockout mice with augmented proliferation and abnormal differentiation of epithelial cells. EMBO J 16:1850-1857

Aviles M, Okinaga T, Shur BD, Ballesta J 2000 Differential expression of glycoside residues in the mammalian zona pellucida. Mol Reprod Dev 57:296-308

Bedford JM 1998 Mammalian fertilization misread? Sperm penetration of the eutherian zona pellucida is unlikely to be a lytic event. Biol Reprod 59:1275-1287

Begovac PC, Hall DE, Shur BD 1991 Laminin fragment E8 mediates PC12 cell neurite outgrowth by binding to cell surface $\beta 1$,4galactosyltransferase. J Cell Biol 113:637-644 
Bigler D, Takahashi Y, Chen MS, Almeida EA, Osbourne L, White JM 2000 Sequence-specific interaction between the disintegrin domain of mouse ADAM 2 (fertilin $\beta$ ) and murine eggs. Role of the $\alpha(6)$ integrin subunit. J Biol Chem 275:11576-11584

Bleil JD, Wassarman PM 1980 Mammalian sperm-egg interaction: identification of a glycoprotein in mouse egg zonae pellucidae possessing receptor activity for sperm. Cell 20:873-882

Bleil JD, Wassarman PM 1983 Sperm-egg interactions in the mouse: sequence of events and induction of the acrosome reaction by a zona pellucida glycoprotein. Dev Biol 95:317-324

Bleil JD, Wassarman PM 1986 Autoradiographic visualization of the mouse egg's sperm receptor bound to sperm. J Cell Biol 102:1363-1371

Bleil JD, Wassarman PM 1988 Galactose at the nonreducing terminus of O-linked oligosaccharides of mouse egg zona pellucida glycoprotein ZP3 is essential for the glycoprotein's sperm receptor activity. Proc Natl Acad Sci USA 85:6778-6782

Bleil JD, Greve JM, Wassarman PM 1988 Identification of a secondary sperm receptor in the mouse egg zona pellucida: role in maintenance of binding of acrosome-reacted sperm to eggs. Dev Biol 128:376-385

Bookbinder LH, Cheng A, Bleil JD 1995 Tissue- and species-specific expression of sp56, a mouse sperm fertilization protein. Science 269:86-89

Bork P 1996 Sperm-egg binding protein or proto-oncogene? Science 271:1431-1432

Borsig L, Kleene R, Dinter A, Berger EG 1996 Immunodetection of alpha 1-3 fucosyltransferase (FucT-V). Eur J Cell Biol 70:42-53

Brewis IA, Clayton R, Barratt CL, Hornby DP, Moore HD 1996 Recombinant human zona pellucida glycoprotein 3 induces calcium influx and acrosome reaction in human spermatozoa. Mol Hum Reprod 2:583-589

Burkin HR, Miller DJ 2000 Zona pellucida protein binding ability of porcine sperm during epididymal maturation and the acrosome reaction. Dev Biol 222:99-109

Burks DJ, Carballada R, Moore HDM, Saling PM 1995 Interaction of a tyrosine kinase from human sperm with the zona pellucida at fertilization. Science 269:83-86

Carroll J 2001 The initiation and regulation of $\mathrm{Ca}^{2+}$ signalling at fertilization in mammals. Semin Cell Dev Biol 12:37-43

Charron M, Shaper NL, Rajput B, Shaper JH 1999 A novel 14-base-pair regulatory element is essential for in vivo expression of murine beta4-galactosyltransferase-I in late pachytene spermatocytes and round spermatids. Mol Cell Biol 19:5823-5832

Chen J, Litscher ES, Wassarman PM 1998 Inactivation of the mouse sperm receptor, mZP3, by site-directed mutagenesis of individual serine residues located at the combining site for sperm. Proc Natl Acad Sci USA 95:6193-6197

Chen MS, Tung KS, Coonrod SA, Takahashi Y, Bigler D, Chang A, Yamashita Y, Kincade PW, Herr JC, White JM 1999 Role of the integrin-associated protein CD9 in binding between sperm ADAM 2 and the egg integrin alpha6beta1: implications for murine fertilization. Proc Natl Acad Sci USA 96:11830-11835

Cheng A, Le T, Palacios M, Bookbinder LH, Wassarman PM, Suzuki F, Bleil JD 1994 Sperm-egg recognition in the mouse: characterization of sp56, a sperm protein having specific affinity for ZP3. J Cell Biol 125:867-878

Cho C, Bunch DO, Faure JE, Goulding EH, Eddy EM, Primakoff P, Myles DG 1998 Fertilization defects in sperm from mice lacking fertilin $\beta$. Science 281:1857-1859

Close BE, Colley KJ 1998 In vivo autopolysialylation and localization of the polysialyltransferases PST and STX. J Biol Chem 273:34586-34593

Colley KJ 1997 Golgi localization of glycosyltransferases: more questions than answers. Glycobiology 7:1-13

Cornwall GA, Tulsiani DR, Orgebin-Crist MC 1991 Inhibition of the mouse sperm surface $\alpha$-D-mannosidase inhibits sperm-egg binding in vitro. Biol Reprod 44:913-921 
Cunningham BC, Ultsch M, de Vos AM, Mulkerrin MG, Clauser KR, Wells JA 1991 Dimerization of the extracellular domain of the human growth hormone receptor by a single hormone molecule. Science 254:821-825

Easton RL, Patankar MS, Lattanzio FA, Leaven TH, Morris HR, Clark GF, Dell A 2000 Structural analysis of murine zona pellucida glycans. Evidence for the expression of core 2-type O-glycans and the $\mathrm{Sd}^{\mathrm{a}}$ antigen. J Biol Chem 275:7731-7742

Ensslin M, Vogel T, Calvete JJ, Thole HH, Schmidtke J, Matsuda T, Topfer-Petersen E 1998 Molecular cloning and characterization of $\mathrm{P} 47$, a novel boar sperm- associated zona pellucidabinding protein homologous to a family of mammalian secretory proteins. Biol Reprod 58:1057-1064

Erlichman J, Gutierrez-Juarez R, Zucker S, Mei X, Orr GA 1999 Developmental expression of the protein kinase $\mathrm{C}$ substrate/binding protein (clone 72/SSeCKS) in rat testis identification as a scaffolding protein containing an A-kinase-anchoring domain which is expressed during late-stage spermatogenesis. Eur J Biochem 263:797-805

Evans JP 2001 Fertilin beta and other ADAMs as integrin ligands: insights into cell adhesion and fertilization. Bioessays 23:628-639

Evans JP, Schultz RM, Kopf GS 1995 Mouse sperm-egg plasma membrane interactions: analysis of roles of egg integrins and the mouse sperm homologue of PH-30 (fertilin) beta. J Cell Sci 108:3267-3278

Evans JP, Kopf GS, Schultz RM 1997 Characterization of the binding of recombinant mouse sperm fertilin $\beta$ subunit to mouse eggs: evidence for adhesive activity via an egg $\beta 1$ integrinmediated interaction. Dev Biol 187:79-93

Fayrer-Hosken RA, Caudle AB, Shur BD 1991 Galactosyltransferase activity is restricted to the plasma membranes of equine and bovine sperm. Mol Reprod Dev 28:74-78

Florman HM, Storey BT 1982 Mouse gamete interactions: the zona pellucida is the site of the acrosome reaction leading to fertilization in vitro. Dev Biol 91:121-130

Florman HM, Wassarman PM 1985 O-linked oligosaccharides of mouse egg ZP3 account for its sperm receptor activity. Cell 41:313-324

Florman HM, Bechtol KB, Wassarman PM 1984 Enzymatic dissection of the functions of the mouse egg's receptor function for sperm. Dev Biol 106:243-255

Florman HM, Arnoult C, Kazam I, Li C, O'Toole CMB 1998 A perspective on the control of mammalian fertilization by egg-activated ion channels in sperm: a tale of two channels. Biol Reprod 59:12-16

Foster J, Friday B, Maulit M, Blobel C, Winfrey V, Olson G, Kim K, Gerton G 1997 AM67, a secretory component of the guinea pig sperm acrosomal matrix, is related to mouse sperm protein sp56 and the complement component 4-binding proteins. J Biol Chem 272: $12714-12722$

Frandberg P-A, Doufexis M, Kapas S, Chhajlani V 1998 Amino acid residues in third intracellular loop of melanocortin 1 receptor are involved in G-protein coupling. Biochem Mol Biol Int 46:913-922

Fukami K, Nakao K, Inoue T, Kataoka Y, Kurokawa M, Fissore RA, Nakamura K, Katsuki M, Mikoshiba K, Yoshida N, Takenawa T 2001 Requirement of phospholipase C $\delta 4$ for the zona pellucida-induced acrosome reaction. Science 292:920-923

Geng JG, Raub TJ, Baker CA, Sawada GA, Ma L, Elhammer AP 1997 Expression of a P-selectin ligand in zona pellucida of porcine oocytes and P-selectin on acrosomal membrane of porcine sperm cells. Potential implications for their involvement in sperm-egg interactions. J Cell Biol 137:743-754

Gong XH, Dubois DH, Miller DJ, Shur BD 1995 Activation of a G protein complex by aggregation of $\beta-1,4$ galactosyltransferase on the surface of sperm. Science 269:1718-1721 
Greve LC, Prody GA, Hedrick JL 1985 N-Acetyl- $\beta$-D-glucosaminidase activity in the cortical granules of Xenopus laevis eggs. Gamete Res 12:305-312

Hardy DM, Garbers DL 1995 A sperm membrane protein that binds in a species-specific manner to the egg extracellular matrix is homologous to von Willebrand factor. J Biol Chem 270:26025-26028

Hickox JR, Bi M, Hardy DM 2001 Heterogeneous processing and zona pellucida-binding activity of pig zonadhesin. J Biol Chem 276:41502-41509

Hunnicutt GR, Primakoff P, Myles DG 1996 Sperm surface protein PH-20 is bifunctional: one activity is a hyaluronidase and a second, distinct activity is required in secondary sperm-zona binding. Biol Reprod 55:80-86

Iida H, Yoshinaga Y, Tanaka S, Toshimori K, Mori T 1999 Identification of Rab3A GTPase as an acrosome-associated small GTP-binding protein in rat sperm. Dev Biol 211:144-155

Jansen S, Ekhlasi-Hundrieser M, Topfer-Petersen E 2001 Sperm adhesion molecules: structure and function. Cells Tiss Organs 168:82-92

Johnston DS, Wright WW, Shaper JH, Hokke CH, Van den Eijnden DH, Joziasse DH 1998 Murine sperm-zona binding, a fucosyl residue is required for a high affinity sperm-binding ligand. J Biol Chem 273:1888-1895

Jones R, Brown CR, Lancaster RT 1988 Carbohydrate-binding properties of boar sperm proacrosin and assessment of its role in sperm-egg recognition and adhesion during fertilization. Development 102:781-792

Joziasse DH 1992 Mammalian glycosyltransferases: genomic organization and protein structure. Glycobiology 2:271-277

Jungnickel MK, Marrero H, Birnbaumer L, Lemos JR, Florman HM 2001 Trp2 regulates entry of $\mathrm{Ca}^{2+}$ into mouse sperm triggered by egg ZP3. Nature Cell Biol 3:499-502

Kaji K, Oda S, Shikano T, Ohnuki T, Uematsu Y, Sakagami J, Tada N, Miyazaki S, Kudo A 2000 The gamete fusion process is defective in eggs of Cd9-deficient mice. Nature Genet 24:279-282

Kim KS, Cha MC, Gerton GL 2001a Mouse sperm protein sp56 is a component of the acrosomal matrix. Biol Reprod 64:36-43

Kim KS, Foster JA, Gerton GL 2001b Differential release of guinea pig sperm acrosomal components during exocytosis. Biol Reprod 64:148-156

Kinloch RA, Mortillo S, Stewart CL, Wassarman PM 1991 Embryonal carcinoma cells transfected with ZP3 genes differentially glycosylate similar polypeptides and secrete active mouse sperm receptor. J Cell Biol 115:655-664

Kline D, Kopf GS, Muncy LF, Jaffe LA 1991 Evidence for the involvement of a pertussis toxin-insensitive $\mathrm{G}$ protein in egg activation of the frog, Xenopus laevis. Dev Biol 143: $218-229$

Korner C, Nurnberg B, Uhde M, Braulke T 1995 Mannose 6-phosphate/insulin-like growth factor II receptor fails to interact with G-proteins. J Biol Chem 270:287-295

Kudo K, Yonezawa N, Katsumata T, Aoki H, Nakano M 1998 Localization of carbohydrate chains of pig sperm ligand in the glycoprotein ZPB of egg zona pellucida. Eur J Biochem 252:492-499

Larson JL, Miller DJ 1997 Sperm from a variety of mammalian species express $\beta 1$,4-galactosyltransferase on their surface. Biol Reprod 57:442-453

Le Naour F, Rubinstein E, Jasmin C, Prenant M, Boucheix C 2000 Severely reduced female fertility in CD9-deficient mice. Science 287:319-321

Lee NH, Geoghagen NSM, Cheng E, Cline RT, Fraser CM 1996 Alanine scanning mutagenesis of conserved arginine/lysine-arginine/lysine-X-X-arginine/lysine $\mathrm{G}$ protein-activating motifs on $\mathrm{m} 1$ muscarinic acetylcholine receptors. Mol Pharmacol 50:140-148 
Leyton L, Saling P 1989a 95 kd sperm proteins bind ZP3 and serve as tyrosine kinase substrates in response to zona binding. Cell 57:1123-1130

Leyton L, Saling P 1989b Evidence that aggregation of mouse sperm receptors by ZP3 triggers the acrosome reaction. J Cell Biol 108:2163-2168

Liang M, Garrison JC 1991 The epidermal growth factor receptor is coupled to a pertussis toxin-sensitive guanine nucleotide regulatory protein in rat hepatocytes. J Biol Chem 266: 13342-13349

Lin X, Tombler E, Nelson PJ, Ross M, Gelman IH 1996 A novel src- and ras-suppressed protein kinase C substrate associated with cytoskeletal architecture. J Biol Chem 271:28430-28438

Litscher ES, Wassarman PM 1996 Recombinant hamster sperm receptors that exhibit speciesspecific binding to sperm. Zygote 4:229-236

Litscher ES, Juntunen K, Seppo A, Penttila L, Niemela R, Renkonen O, Wassarman PM 1995 Oligosaccharide constructs with defined structures that inhibit binding of mouse sperm to unfertilized eggs in vitro. Biochemistry 34:4662-4669

Loeser CR, Tulsiani DR 1999 The role of carbohydrates in the induction of the acrosome reaction in mouse spermatozoa. Biol Reprod 60:94-101

Lopez LC, Bayna EM, Litoff D, Shaper NL, Shaper JH, Shur BD 1985 Receptor function of mouse sperm surface galactosyltransferase during fertilization. J Cell Biol 101:1501-1510

Lu Q, Shur BD 1997 Sperm from $\beta$ 1,4-galactosyltransferase-null mice are refractory to ZP3-induced acrosome reaction and penetrate the zona pellucida poorly. Development 124:4121-4131

Lu Q, Hasty P, Shur BD 1997 Targeted mutation in $\beta 1$,4-galactosyltransferase leads to pituitary insufficiency and neonatal lethality. Dev Biol 181:257-267

Lyon JD, Vacquier VD 1999 Interspecies chimeric sperm lysins identify regions mediating species-specific recognition of the abalone egg vitelline envelope. Dev Biol 214:151-159

Macek MB, Lopez LC, Shur BD 1991 Aggregation of $\beta$-1,4-galactosyltransferase on mouse sperm induces the acrosome reaction. Dev Biol 147:440-444

Mandel U, Hassan H, Therkildsen MH, Rygaard J, Jakobsen MH, Juhl BR, Dabelsteen E, Clausen H 1999 Expression of polypeptide GalNAc-transferases in stratified epithelia and squamous cell carcinomas: immunohistological evaluation using monoclonal antibodies to three members of the GalNAc-transferase family. Glycobiology 9:43-52

Martin I, Epand RM, Ruysschaert JM 1998 Structural properties of the putative fusion peptide of fertilin, a protein active in sperm-egg fusion, upon interaction with the lipid bilayer. Biochemistry 37:17030-17039

Mayadas TN, Johnson RC, Rayburn H, Hynes RO, Wagner DD 1993 Leukocyte rolling and extravasation are severely compromised in P selectin-deficient mice. Cell 74:541-554

Mengel-Gaw L, McCoy-Maman M, Tiemeier D 1991 Genomic structure and expression of human $\beta$-1,4-galactosyltransferase. Biochem Biophys Res Commun 176:1269-1276

Milland J, Taylor SG, Dodson HC, McKenzie IF, Sandrin MS 2001 The cytoplasmic tail of $\alpha 1,2$-fucosyltransferase contains a sequence for golgi localization. J Biol Chem 276: 12012-12018

Miller BJ, Georges-Labouesse E, Primakoff P, Myles DG 2000 Normal fertilization occurs with eggs lacking the integrin $\alpha 6 \beta 1$ and is CD9-dependent. J Cell Biol 149:1289-1296

Miller DJ, Macek MB, Shur BD 1992 Complementarity between sperm surface $\beta$-1,4-galactosyltransferase and egg-coat ZP3 mediates sperm-egg binding. Nature 357:589-593

Miller DJ, Gong XH, Decker G, Shur BD 1993 Egg cortical granule $N$-acetylglucosaminidase is required for the mouse zona block to polyspermy. J Cell Biol 123:1431-1440

Miyado K, Yamada G, Yamada S, Hasuwa H, Nakamura Y, Ryu F, Suzuki K, Kosai K, Inoue K, Ogura A, Okabe M, Mekada E 2000 Requirement of CD9 on the egg plasma membrane for fertilization. Science 287:321-324 
Moller CC, Bleil JD, Kinloch RA, Wassarman PM 1990 Structural and functional relationships between mouse and hamster zona pellucida glycoproteins. Dev Biol 137:276-286

Moller CC, Wassarman PM 1989 Characterization of a proteinase that cleaves zona pellucida glycoprotein ZP2 following activation of mouse eggs. Dev Biol 132:103-112

Mori E, Kashiwabara S, Baba T, Inagaki Y, Mori T 1995 Amino acid sequences of porcine Sp38 and proacrosin required for binding to the zona pellucida. Dev Biol 168:575-583

Mortillo S, Wassarman PM 1991 Differential binding of gold-labeled zona pellucida glycoproteins mZP2 and mZP3 to mouse sperm membrane components. Development 113:141-149

Myles DG, Primakoff P 1997 Why did the sperm cross the cumulus? To get to the oocyte. Functions of the sperm surface proteins $\mathrm{PH}-20$ and fertilin in arriving at, and fusing with, the egg. Biol Reprod 56:320-327

Myles DG, Kimmel LH, Blobel CP, White JM, Primakoff P 1994 Identification of a binding site in the disintegrin domain of fertilin required for sperm-egg fusion. Proc Natl Acad Sci USA 91:4195-4198

Nakano M, Yonezawa N 2001 Localization of sperm ligand carbohydrate chains in pig zona pellucida glycoproteins. Cells Tiss Organs 168:65-75

Nishimoto I, Okamoto T, Matsuura Y, Takahashi S, Okamoto T, Murayama Y, Ogata E 1993 Alzheimer amyloid protein precursor complexes with brain GTP-binding protein $\mathrm{G}_{\mathrm{o}}$. Nature 362:75-79

Nishimura H, Cho C, Branciforte DR, Myles DG, Primakoff P 2001 Analysis of loss of adhesive function in sperm lacking cyritestin or fertilin beta. Dev Biol 233:204-213

Nixon B, Lu Q, Wassler MJ, Foote CI, Ensslin MA, Shur BD 2001 Galactosyltransferase function during mammalian fertilization. Cells Tiss Organs 168:46-57

Okamoto T, Katada T, Murayama Y, Ui M, Ogata E, Nishimoto I 1990 A simple structure encodes G-protein activating function of the IGF-II mannose 6-phosphate receptor. Cell 62:709-717

Olate J, Martinez S, Purcell P, Jorquera H, Codina J, Birnbaumer L, Allende J 1990 Molecular cloning and sequence determination of four different cDNA species coding for alpha-subunits of $\mathrm{G}$ proteins from Xenopus laevis oocytes. FEBS Lett 268:27-31

Palumbi SR 1999 All males are not created equal: fertility differences depend on gamete recognition polymorphisms in sea urchins. Proc Natl Acad Sci USA 96:12632-12637

Perry AC, Wakayama T, Cooke IM, Yanagimachi R 2000 Mammalian oocyte activation by the synergistic action of discrete sperm head components: induction of calcium transients and involvement of proteolysis. Dev Biol 217:386-393

Pratt SA, Shur BD $1993 \beta$-1,4-Galactosyltransferase expression during spermatogenesis: stagespecific regulation by $t$ alleles and uniform distribution in + -spermatids and $t$-spermatids. Dev Biol 156:80-93

Ramalho-Santos J, Moreno RD, Sutovsky P, Chan AW, Hewitson L, Wessel GM, Simerly CR, Schatten G 2000 SNAREs in mammalian sperm: possible implications for fertilization. Dev Biol 223:54-69

Rankin T, Dean J 2000 The zona pellucida: using molecular genetics to study the mammalian egg coat. Rev Reprod 5:114-121

Rankin TL, Tong ZB, Castle PE, Lee E, Gore-Langton R, Nelson LM, Dean J 1998 Human ZP3 restores fertility in Zp3 null mice without affecting order-specific sperm binding. Development 125:2415-2424

Rankin T, Talbot P, Lee E, Dean J 1999 Abnormal zonae pellucidae in mice lacking ZP1 result in early embryonic loss. Development 126:3847-3855

Rebeiz M, Miller DJ 1999 Porcine sperm surface $\beta 1$,4galactosyltransferase binds to the zona pellucida but is not necessary or sufficient to mediate sperm-zona pellucida binding. Mol Reprod Dev 54:379-387 
Russo RN, Shaper NL, Shaper JH 1990 Bovine $\beta 1$,4-galactosyltransferase: two sets of mRNA transcripts encode two forms of the protein with different amino-terminal domains. J Biol Chem 265:3324-3331

Sasai K, Ikeda Y, Tsuda T, Ihara H, Korekane H, Shiota K, Taniguchi N 2001 The critical role of the stem region as a functional domain responsible for the oligomerization and Golgi localization of $\mathrm{N}$-acetylglucosaminyltransferase $\mathrm{V}$. The involvement of a domain homophilic interaction. J Biol Chem 276:759-765

Schmell ED, Gulyas BJ 1980 Mammalian sperm-egg recognition and binding in vitro. I. Specificity of sperm interactions with live and fixed eggs in homologous and heterologous insemination of hamster, mouse, and guinea pig oocytes. Biol Reprod 23:1075-1085

Schulz JR, Wessel GM, Vacquier VD 1997 The exocytosis regulatory proteins syntaxin and VAMP are shed from sea urchin sperm during the acrosome reaction. Dev Biol 191:80-87

Scully NF, Shaper JH, Shur BD 1987 Spatial and temporal expression of cell surface galactosyltransferase during mouse spermatogenesis and epididymal maturation. Dev Biol 124:111-124

Shaper NL, Hollis GF, Douglas JG, Kirsch IR, Shaper JH 1988 Characterization of the full length cDNA for murine $\beta 1,4$-galactosyltransferase. Novel features at the $5^{\prime}$-end predict two translational start sites at two in-frame AUGs. J Biol Chem 263:10420-10428

Shaper NL, Charron M, Lo NW, Shaper JH 1998 $\beta 1,4$-Galactosyltransferase and lactose biosynthesis: recruitment of a housekeeping gene from the nonmammalian vertebrate gene pool for a mammary gland specific function. J Mammary Gland Biol Neoplasia 3:315-324

Shi X, Amindari S, Paruchuru K, Skalla D, Burkin H, Shur BD, Miller DJ 2001 Cell surface $\beta$-1,4-galactosyltransferase-I activates G protein-dependent exocytotic signaling. Development 128:645-654

Shimizu S, Tsuji M, Dean J 1983 In vitro biosynthesis of three sulfated glycoproteins in murine zonae pellucidae by oocytes grown in follicle culture. J Biol Chem 258:5858-5863

Shur BD 1991 Cell surface $\beta 1$,4galactosyltransferase: twenty years later. Glycobiology 1:563-575

Shur BD 1993 Glycosyltransferasess as cell adhesion molecules. Curr Opin Cell Biol 5:854-863

Shur BD, Hall NG 1982a A role for mouse sperm surface galactosyltransferase in sperm binding to the egg zona pellucida. J Cell Biol 95:574-579

Shur BD, Hall NG 1982b Sperm surface galactosyltransferase activities during in vitro capacitation. J Cell Biol 95:567-573

Shur BD, Neely CA 1988 Plasma membrane association, purification, and partial characterization of mouse sperm $\beta 1$,4-galactosyltransferase. J Biol Chem 263:17706-17714

Stricker SA 1999 Comparative biology of calcium signaling during fertilization and egg activation in animals. Dev Biol 211:157-176

Sun H, Chen Z, Poppleton H, Scholich K, Mulenix J, Weipz GJ, Fulgham DL, Bertics PJ, Patel TB 1997 The juxtamembrane, cytosolic region of the epidermal growth factor receptor is involved in association with $\alpha$-subunit of $\mathrm{G}_{\mathrm{s}}$. J Biol Chem 272:5413-5420

Swanson WJ, Vacquier VD 1997 The abalone egg vitelline envelope receptor for sperm lysin is a giant multivalent molecule. Proc Natl Acad Sci USA 94:6724-6729

Swanson WJ, Vacquier VD 1998 Concerted evolution in an egg receptor for a rapidly evolving abalone sperm protein. Science 281:710-712

Swanson WJ, Yang Z, Wolfner MF, Aquadro CF 2001 Positive Darwinian selection drives the evolution of several female reproductive proteins in mammals. Proc Natl Acad Sci USA 98:2509-2514

Takahashi Y, Bigler D, Ito Y, White JM 2001 Sequence-specific interaction between the disintegrin domain of mouse ADAM 3 and murine eggs: role of $\beta 1$ integrin-associated proteins CD9, CD81, and CD98. Mol Biol Cell 12:809-820 
Tengowski MW, Wassler MJ, Shur BD, Schatten G 2001 Subcellular localization of $\beta 1,4-$ galactosyltransferase on bull sperm and its function during sperm-egg interactions. Mol Reprod Dev 58:236-244

Thaler CD, Cardullo RA 1996 The initial molecular interaction between mouse sperm and the zona pellucida is a complex binding event. J Biol Chem 271:23289-23297

Thall AD, Maly P, Lowe JB 1995 Oocyte Gal $\alpha 11,3 \mathrm{Gal}$ epitopes implicated in sperm adhesion to the zona pellucida glycoprotein ZP3 are not required for fertilization in the mouse. J Biol Chem 270:21437-21440

Tsai J-Y, Silver L 1996 Sperm-egg binding protein or proto-oncogene. Science 271:1431-1432

van Duin M, Polman JE, De Breet IT, van Ginneken K, Bunschoten H, Grootenhuis A, Brindle J, Aitken RJ 1994 Recombinant human zona pellucida protein ZP3 produced by chinese hamster ovary cells induces the human sperm acrosome reaction and promotes sperm-egg fusion. Biol Reprod 51:607-617

Visconti PE, Kopf GS 1998 Regulation of protein phosphorylation during sperm capacitation. Biol Reprod 59:1-6

Wade SM, Lim WK, Lan K-L, Chung DA, Nanamori M, Neubig RR 1999 G $_{\mathrm{i}}$ activator region of $\alpha_{2 \mathrm{~A}}$-adrenergic receptors: distinct basic residues mediate $\mathrm{G}_{\mathrm{i}}$ versus $\mathrm{G}_{\mathrm{s}}$ activation. Mol Pharmacol 56:1005-1013

Walensky LD, Snyder SH 1995 Inositol 1,4,5-trisphosphate receptors selectively localized to the acrosomes of mammalian sperm. J Cell Biol 130:857-869

Wang H-L 1999 A conserved arginine in the distal third intracellular loop of the micro-opioid receptor is required for $\mathrm{G}$ protein activation. J Neurochem 72:1307-1314

Ward CR, Kopf GS 1993 Molecular events mediating sperm activation. Dev Biol 158:9-34

Ward CR, Storey BT, Kopf GS 1992 Activation of $\mathrm{G}_{\mathrm{i}}$ protein in mouse sperm membranes by solubilized proteins of the zona pellucida, the egg's extracellular matrix. J Biol Chem 267:14061-14070

Ward C, Storey B, Kopf GS 1994 Selective activation of $\mathrm{G}_{\mathrm{i} 1}$ and $\mathrm{G}_{\mathrm{i} 2}$ in mouse sperm by the zona pellucida, the egg's extracellular matrix. J Biol Chem 269:13254-13258

Wassarman PM, Litscher ES 2001 Towards the molecular basis of sperm and egg interaction during mammalian fertilization. Cells Tiss Organs 168:36-45

Wassarman PM, Jovine L, Litscher ES 2001 A profile of fertilization in mammals. Nature Cell Biol 3:E59-E64

Wassler MJ, Foote CI, Gelman IH, Shur BD 2001 Functional interaction between the SSeCKS scaffolding protein and the cytoplasmic domain of $\beta 1$,4-galactosyltransferase. J Cell Sci 114:2291-2300

Wen Y, Richardson RT, Widgren EE, O'Rand MG 2001 Characterization of Sp17: a ubiquitous three domain protein that binds heparin. Biochem J 357:25-31

Wolfe CA, Cladera J, Ladha S, Senior S, Jones R, O'Shea P 1999 Membrane interactions of the putative fusion peptide $(\mathrm{MF} \alpha \mathrm{P})$ from fertilin- $\alpha$, the mouse sperm protein complex involved in fertilization. Mol Membr Biol 16:257-263

Wu H, Smyth J, Luzzi V, Fukami K, Takenawa T, Black SL, Allbritton NL, Fissore RA 2001 Sperm factor induces intracellular free calcium oscillations by stimulating the phosphoinositide pathway. Biol Reprod 64:1338-1349

Xie W, Jiang H, Wu Y, Wu D 1997 Two basic amino acids in the second inner loop of the interleukin-8 receptor are essential for G $\alpha 16$ coupling. J Biol Chem 272:24948-24951

Yamagata K, Murayama K, Okabe M, Toshimori K, Nakanishi T, Kashiwabara S, Baba T 1999 Acrosin accelerates the dispersal of sperm acrosomal proteins during acrosome reaction. J Biol Chem 273:10470-10474 
Yamaguchi N, Fukuda MN 1995 Golgi retention mechanism of $\beta$-1,4-galactosyltransferase. Membrane-spanning domain-dependent homodimerization and association with $\alpha$ - and $\beta$ tubulins. J Biol Chem 270:12170-12176

Yamasaki N, Richardson RT, O'Rand MG 1995 Expression of the rabbit sperm protein Sp17 in COS cells and interaction of recombinant Sp17 with the rabbit zona pellucida. Mol Reprod Dev 40:48-55

Yanagimachi R 1994 Mammalian fertilization. In: Knobil E, Neill JD, eds. Physiology of Reproduction, 2nd edit. New York: Raven Press; A189-A317

Yang L, Baffy G, Rhee SG, Manning D, Hansen CA, Williamson JR 1991 Pertussis toxinsensitive $G_{i}$ protein involvement in epidermal growth factor-induced activation of phospholipase C- $\gamma$ in rat hepatocytes. J Biol Chem 266:22451-22458

Yonezawa N, Mitsui S, Kudo K, Nakano M 1997 Identification of an N-glycosylated region of pig zona pellucida glycoprotein ZPB that is involved in sperm binding. Eur J Biochem 248:86-92

Yonezawa N, Fukui N, Kuno M, Shinoda M, Goko S, Mitsui S, Nakano M 2001 Molecular cloning of bovine zona pellucida glycoproteins ZPA and ZPB and analysis for sperm-binding component of the zona. Eur J Biochem 268:3587-3594

Youakim A, Dubois D, Shur B 1994a Localization of the long form of $\beta$-1,4-galactosyltransferase to the plasma membrane and Golgi complex of 3T3 and F9 cells by immunofluorescence confocal microscopy. Proc Natl Acad Sci USA 91:10913-10917

Youakim A, Hathaway HJ, Miller DJ, Gong X, Shur BD 1994b Overexpressing sperm surface $\beta 1,4$-galactosyltransferase in transgenic mice affects multiple aspects of sperm-egg interactions. J Cell Biol 126:1573-1583

Yuan R, Primakoff P, Myles DG 1997 A role for the disintegrin domain of cyritestin, a sperm surface protein belonging to the ADAM family, in mouse sperm-egg plasma membrane adhesion and fusion. J Cell Biol 137:105-112

Yurewicz EC, Pack BA, Sacco AG 1992 Porcine oocyte zona pellucida Mr 55,000 glycoproteins: identification of O-glycosylated domains. Mol Reprod Dev 33:182-188

Yurewicz EC, Sacco AG, Gupta SK, Xu N, Gage DA 1998 Hetero-oligomerization-dependent binding of pig oocyte zona pellucida glycoproteins ZPB and ZPC to boar sperm membrane vesicles. J Biol Chem 273:7488-7494

Zhu G, Allende ML, Jaskiewicz E, Qian R, Darling DS, Worth CA, Colley KJ, Young WW Jr 1998 Two soluble glycosyltransferases glycosylate less efficiently in vivo than their membrane bound counterparts. Glycobiology 8:831-840 